\title{
Do Fish Resist? ${ }^{1}$
}

\section{DINESH JOSEPH WADIWEL}

UNIVERSITY OF SYDNEY

In 2010 the UK-based organisation, Fishcount.org.uk, released a pioneering report which attempted to estimate the number of wild sea animals killed each year as part of commercial fishing. Data has been available from national and international organisations on commercial fishing quantities; however, most of these previous measures, such as those maintained by the UN Food and Agriculture Organisation, refer to sea animals produced for food by weight rather than number, thus veiling from public perception the actual number of sea animals which are used by humans. ${ }^{2}$ Based on their own research, Fishcount.org.uk and the report's lead author, Alison Mood, proposed a sobering statistic: that between 0.97 and 2.7 trillion wild fish are slaughtered every year through commercial fishing. ${ }^{3}$ In a follow up report, Mood and Phil Brooke attempted to also estimate the number of fish killed annually through fish farming (or aquaculture): their estimate in 2012 was that this was of the order of 37 to 120 billion per year. ${ }^{4}$ (To put these figures in perspective, the UN Food and Agriculture Organisation data indicates that in 2010, 63 billion

ISSN 1837-8692

Cultural Studies Review 2016. () 2016 Dinesh Joseph Wadiwel. This is an Open Access article distributed under the terms of the Creative Commons Attribution 4.0 Unported (CC BY 4.0) License (https://creativecommons.org/licenses/by/4.0/), allowing third parties to copy and redistribute the material in any medium or format and to remix, transform, and build upon the material for any purpose, even commercially, provided the original work is properly cited and states its license. 
land animals were slaughtered for human consumption, a figure that is likely to be close to 70 billion for the year just past.) ${ }^{5}$ These figures do not include the potentially large numbers of fish caught globally through recreational fishing practices. ${ }^{6}$

We know that the global use of sea animals for food is set to increase. World per capita fish consumption has more or less doubled in the last fifty years (from 9.9 kilgrams to19.2 kilograms per person per year), meaning that not only are more fish being killed to feed a larger human population across the globe, but on average humans are eating more fish per person than ever before. ${ }^{7}$ Concern around industrial wild fish capture, particularly the effects of this exponential increase in human utilisation, has also been the focus of environmental concern. The UN Food and Agriculture Organisation claims that in 2011 some '28.8 percent of fish stocks were estimated as fished at a biologically unsustainable level'.8 It is little wonder that Nobel Prize winner Paul Crutzen, in proposing the geological time period of the 'Anthropocene', singled out mechanised fishing as one example of a significant area of planetary scale human impact. Crutzen noted in 2002 that 'fisheries remove more than $25 \%$ of the primary production in upwelling ocean regions and $35 \%$ in the temperate continental shelf'. ${ }^{9}$ Human wild fish capture certainly accounts for the largest proportion of all fish caught globally; however, industrialised fishing is shifting from the use of mechanised predation towards intensive fish farming in the context of aquaculture. Following an explosion in the use of aquaculture since the 1990s (at a growth rate of around 9.5 per cent per year), farmed fish now account for a sizeable proportion of all fish killed for human use, standing at around 42 per cent of all fish slaughtered. ${ }^{10}$ Today fish farming has overtaken beef farming globally as a source of animal protein. ${ }^{11}$ Aquaculture-factory farms for fish-looks to be positioned as an essential element within global food supply.

The welfare picture in the context of industrialised fishing is frightening. ${ }^{12}$ Despite the huge scale of the industry, there is little evidence that significant welfare precautions are taken in fishing practices to reduce the suffering fish experience as part of their use by humans. There are a number of publicly documented welfare concerns surrounding recreational and industrial fishing practices, including around line fishing, net fishing and the trauma associated with the capture and transport of live fish. ${ }^{13}$ However, arguably, the mode of slaughter used to kill fish in most fishing 
industry practices offers us the most telling insight into the poverty of current basic welfare protections available to fish that are used by humans. By far the most prevalent means of slaughter by the fishing industry is death by asphyxiation, where fish are left in the open air to die slowly as their bodies are deprived of oxygen. Fish usually take a long time to die this way, and studies have shown that the period until stunning-that is, the period during which fish suffer before they are unconsciousis considerable. Rainbow trout take some fifteen minutes before they are stunned; sea bream twenty-five minutes and sea bass sixty minutes. ${ }^{14}$ The prevalent practice of placing live fish on an ice slurry is no better; indeed is likely to further prolong the time before fish are effectively stunned. Studies have shown that trout take between twenty-eight and 198 minutes to be stunned using this method; salmon sixty minutes, and sea bream twenty to forty minutes. ${ }^{15}$ Many fish are subject to live gutting as part of the slaughter process. Some fish continue to live during and after being gutted; one study indicates that stunning times vary between twenty-five and sixty minutes for gutted fish. ${ }^{16}$ The use of carbon dioxide to stun fish may speed up stunning periods. But this may also lead to a 'quick and violent reaction, such as repeated swimming around, attempts to escape from the tub and abnormal activity before stunning'. ${ }^{17}$ In some cases, sea animals may take a relatively long time to be stunned using carbon dioxide; for example 109 minutes for eels. ${ }^{18}$ Many fish are indirectly killed or injured by nets, hooks or other fish before they land on board a ship (something I discuss below). However, many forms of suffering are directly, intentionally, imposed on fish as part of the killing process, often as a means to produce a desired marketable commodity at the end of the process (that is, fish meat). One example is cutting fish across the gills and returning them alive to the water. This uses the beating heart of the fish while it is still alive to flush blood from its body, supposedly to produce a desirable effect on fish meat in terms of taste and appearance. In the case of eels, it is common practice to place them in a saltwater bath to 'deslime them'-a process to which eels are aversive-before being eviscerated alive. The whole ordeal takes some twenty minutes. ${ }^{19}$

These visceral horrors are part and parcel of fishing and fishing industries, but the advocacy challenge for pro-animal activists, scholars and workers remains daunting. While legal protections are offered to many land animals routinely used for food, the same protections are not available for fish. ${ }^{20}$ In part, this situation is a 
result of a lack of agreement that fish are capable of suffering, or at least that this suffering matters. There is some recognition that land animals used for food, experiments and recreation can suffer at human hands, and this shapes welfare laws and regulation aimed at minimising this suffering. ${ }^{21}$ This in turn shapes the advocacy arguments made by animal advocates on behalf of land animals, which usually involve balancing animal suffering against human utility. ${ }^{22}$ In the case of fish, there is no universal acceptance that fish suffer, which in turn shapes the advocacy task. Advocates are forced to argue first that fish do indeed suffer (since this is contentious), and then, subsequently, argue for minimal (and often very minimal) welfare measures to be adopted to mitigate the intense volume of this suffering. ${ }^{23}$

This situation-where advocates must argue that fish feel pain since this knowledge is not taken for granted-is at least in part a result of the uncertain science on fish suffering. There are many scientific studies which have shown that some fish do feel pain and that this has significant welfare implications. In 2003, for example, Lynne Sneddon and her colleagues performed experiments on rainbow trout. They observed aversive behaviours to potentially painful experiences and also observed that administering morphine to the fish significantly reduced pain-related behaviours. ${ }^{24}$ These studies, and the problems they raise, were further expanded upon by one of Sneddon's co-researchers, Victoria Braithwaite, in her 2010 book Do Fish Feel Pain?25 Against this view, other scientists have consistently argued, perhaps as an echo of the view that is attributed to Descrates' that animals are mere automata (bête-machine), that fish do not experience suffering, only reaction to stimuli. ${ }^{26}$ Notably James D. Rose and his fellow researchers in 2012 contested the view that fish could experience pain in the way humans do. The researchers argued:

even if fishes were conscious, it is unwarranted to assume that they possess a human-like capacity for pain. Overall, the behavioural and neurobiological evidence reviewed shows fish responses to nociceptive stimuli are limited and fishes are unlikely to experience pain. ${ }^{27}$

The uncertainty within the scientific community over whether fish feel pain, combined with a public attachment to the maintenance of existing fishing practices, produces a somewhat perverse silence in relation to fish welfare. The lack of consistent agreement on the question of fish suffering leads to inaction. It limits the capacity of policy makers to take decisive steps towards mitigating fish suffering. As 
Celeste Black puts it: 'the absence of a consensus on the basic issue of fish suffering may be used as grounds to exclude fish from the reach of animal welfare laws'. ${ }^{28}$ For animal advocates, I would argue that there is now a tactical quandary over how we might respond to the massive human violence directed against fish. We know already that the global expansion of human utilisation of land animals for food represents an extraordinary ethical and political challenge. The reality of growing human use of animals, the expansion of industrialised reproduction, containment and slaughter, combined with limited will from decision makers-indeed most humans - to mitigate their use of animals, means prospects of change in favour of land animals remains slim. As Sue Donaldson and Will Kymlicka have frankly noted: 'for the foreseeable future, we can expect more and more animals every year to be bred, confined, tortured, exploited, and killed to satisfy human desires'.29 For sea animals the situation looks even more grim: the growing world per capita appetite for fish, the exponential expansion of industrial aquaculture, and limited public agreement on the question of fish suffering, all suggest that fish welfare will continue to be a low priority in the face of a massive restructuring of global human consumption towards fish-based protein.

It is with this in mind that in this article I now abandon the question of fish suffering - at least directly-and focus instead on understanding the potential of the question 'do fish resist?' My interest in resistance is that it offers a different model for considering political agency. If we award moral recognition to animals on the basis of their sentience, then we argue that moral worth depends upon some innate capacity related to sentience (for example the ability to feel pain, or to experience emotions). Classic pro-animal approaches have tried to demonstrate innate capability in order to 'ground' a claim for moral recognition. For example Peter Singer's foundational text, Animal Liberation, uses a utilitarian approach to suffering as a basis to weigh the moral claims of animals; Tom Regan's The Case for Animal Rights instead argues that animals, in so far as they are 'subjects of a life', have an intrinsic moral worth; and Martha Nussbaum applies the capabilities approach to animals to argue that animals have their own needs for flourishing that we must recognise. ${ }^{30}$ Against these approaches, my interest in resistance is that it describes a form of political agency that need not be grounded in an innate capability or worth. If we think about resistance-for example, human political mobilisation against a 
totalitarian dictator-we are not initially concerned with recognising the moral worth of those who resist; we are instead interested in how those who resist are involved in relationships of power. This understanding of resistance draws explicitly from the tradition established by Foucault in understanding resistance as always in relation to power (although, as I discuss in this article, there is scope to build further on this understanding); power describes the existence of contestation. ${ }^{31}$ For Foucault power involves:

mobile and transitory points of resistance, producing cleavages in a society that shift about, fracturing unities and effecting regroupings, furrowing across individuals themselves, cutting them up and remoulding them, marking off irreducible regions in them, in their bodies and minds. ${ }^{32}$

Foucault's view of power as a frictional tussle of forces allows resistive elements within relations of power to be understood as engaging 'agentially' within relations of power without having to demonstrate that those who resist possess capabilities worthy of moral recognition (language, reason, capability for suffering and so on). ${ }^{33}$ Keeping the dynamics of power in the frame, in some respects it is simply enough to understand that if there is power, there must be resistance. Focusing on relations of power and their resistance also allows us to ask whether these relationships of power are 'just' relations, particularly where these relations are violent. Thus, when we think about political resistance to authority, we frequently ask if the resistance is justified, and how those who protest are responding with respect to power. Thinking about resistance opens question of social justice, perhaps without needing to think about whether those who resist have an innate individual capacity that we must ethically recognise (such as the capacity to suffer).

My aim in this article is to explore whether conceptualising fish resistance offers some opportunities to reframe human violence towards sea animals, and whether it offers different tools for advocacy. I use the term 'fish' extraordinarily loosely here to describe 'sea animals'. Others have elsewhere discussed the technical difficulties in deciding between categories of sea animals-aquatic mammals, vertebrates and aquatic invertebrate-and whether these different animals are owed differential welfare consideration. ${ }^{34}$ In keeping with my broad conceptual questions, I will suspend discussion of taxonomic classification of sea animals, and whether these variations suggest differences in how we might understand 
resistance. But my primary focus is on fish that are the object of industrialised fishing. I do not draw from observational studies of fish to 'prove' that fish resist through observed normatively defined behaviours. As I discuss in the following section, part of my challenge is to tackle fish resistance as an 'epistemological problem'; that is, a problem of how we frame human knowledge of fish, and how this shapes what we can know and think is possible. In the second part of the article, I examine existing discussions of resistance within animal studies. I look particularly at the 'autonomous' model of resistance as one that is promising for understanding fish. Finally, I apply this autonomous model of resistance to examining three fishing technologies: the hook, purse seine, and aquaculture. I argue that these technologies, their existence, have been formed against the creative resistance of fish, highlighting that fish do resist and opening a different way to conceptualise the resistance of animals.

\section{—EPISTEMOLOGIES OF FISH RESISTANCE: 'THE FISH ACTUALLY WANTED TO DIE'}

In order to understand fish resistance, it seems worth attending to the question of 'epistemology' and then, the concept of 'epistemic violence'. ${ }^{35}$ In some respects the question 'do fish resist?' can only be answered by deliberating on the question of epistemologies; of what we 'know' and how what we 'know' frames what is possible. I will treat 'epistemology' here as suggesting a system of knowledge or truth: it is within the confines of a system of truth that we may verify whether statements may be true or false, and a system of truth renders the way in which we see and understand the world. One example of an epistemology is the system of knowledge that has been built around the scientific method, which has relied upon making systematic and repeated observations of the world and phenomena, and based upon these observations has theorised what might be true. A related consideration for epistemology is the way we frame a particular issue, how this frame simultaneously situates actors, and how this frame enables what is possible and impossible within any given context.

This understanding of epistemology, which gives preference to understanding the contours, dynamics and effects of what we know as true, rather than seeking to verify what is in itself 'true', is shaped by an explicitly Foucauldian outlook, which comprehends epistemology as constituted by contesting social and political 
processes. $^{36}$ Foucault's method provides a way to understand and reframe the 'scientific' method of progressively completing the documentation of what is true through empirical observation (for example, through experimentation to conclusively determine if fish feel pain), by allowing us to instead understand knowledge as determining what is possible, including what is possible to think:

I am not concerned ... to describe the progress of knowledge towards an objectivity in which today's science can finally be recognized; what I am trying to bring to light is the epistemological field, the episteme in which knowledge, envisaged apart from all criteria having reference to its rational value or to its objective forms, grounds its positivity and thereby manifests a history which is not that of its growing perfection, but rather that of its conditions of possibility. ${ }^{37}$

Here the focus of Foucault's approach is not to evaluate knowledge, or the history of knowledge, by understanding its potential 'proximity' to an objective truth. On the contrary, of more interest to Foucault is understanding how a regime of truth conditions possibility, and in turn how this inflects relations of power.

This approach is incredibly useful for unpacking human relations of power with fish. As I have discussed above, one of the tensions when considering whether fish that are utilised by humans are owed welfare is the current scientific debate over whether fish suffer. It is important to consider the epistemological framing here. The fact that fish suffering is in question, the fact that we need scientists to answer this question before we-humans-decide to take action, demonstrates a problem of framing, where it is impossible to imagine offering welfare to fish-or indeed stop fishing-until verification arrives that fish do indeed suffer.

Perhaps of more concern is that this framing creates apparently rational positions, which are in some respects easily rendered as irrational, and certainly unjustifiable, at least when examined using a different perspective on 'truth'. At present humans kill trillions of fish; many of these fish are hunted and slaughtered (or bred, intensively contained and slaughtered) with minimal (or no) welfare precautions taken. Humans apparently feel able to continue their practices because no science has consistently verified whether fish suffer. There is insufficient evidence to support change, and change is costly.38 On the other hand, we could equally argue that we should not use fish until we are clear on the science of fish 
suffering. Given the gravity of the volume of potential suffering that we may impose on trillions of fish through our use of them, the 'rational position' could easily be that we should not harm fish, or alternatively offer maximal welfare to fish, until such a time comes when we have confirmed evidence, one way or other, on the question of whether fish suffer. Certainly some of the minimal welfare precautions that have been adopted with respect to fish have occurred through this kind of cautious 'benefit of the doubt' approach, but these same precautious have been strongly criticised, precisely because, as I have said, fish suffering has been framed in a way that assumes we can continue using fish the way we do until somebody proves that we should not. 39

I do not raise all of this to call into question the scientific method and its capacity to answer the pressing question: 'Do fish feel pain?' I raise it rather to stress that the epistemology of fish suffering is shaped by a vast human investmentmonetary, infrastructural, dietary, institutional-in precisely making fish suffer, and this has in turn shaped the high stakes of how we see fish and the meaning of the question 'do fish feel pain?' The fact that we utilise fish on a monstrous scale, and in such a way that they are likely to suffer if they have a capacity to suffer, and that we do so without reliable science to confirm that fish do not suffer at our hands, tells us something about the relationship of our system of truth to power, and the way this frames problems and determines subject positions. Instead of asking 'do fish feel pain?,' a different order of question might be: 'How can we use fish the way we do, on the scale we do, when we are still not certain that they do not suffer?'40 Fish and fishing remind us that violence itself is shaped by our systems of knowledge, and as such many of these questions are essentially epistemic in nature. Violence, as it is rendered within the public space and by the politics of suffering, can only be made visible within the context of available knowledge systems. ${ }^{41}$ It is only possible to see violence towards animals when we conceptualise this as possible. ${ }^{42}$ The relative silence around the fishing practices, the large global and industrial scale of this endeavour and the reliance on the scientific project to verify fish suffering, all perhaps indicate that we fundamentally lack the knowledge systems to imagine fish as subjects of violence, or understand fishing as a system of concentrated violence against sea animals. 
In a well known essay called 'Can the Subaltern Speak?,' Gayatri Chakravorty Spivak describes what she calls 'epistemic violence' as a way to understand the capacity of systems of truth to silence particular subjects, and render visible and invisible particular forms of truth and possibility. ${ }^{43}$ Spivak offers the case study of ritual widow burning in India, sati, the practice that was subject to legal regulation by the British as part of their colonising mission in India, and then subject to response from Indian traditionalists claiming the practice as a 'custom'.44 Spivak draws attention to the way in which a system of truth shaped the narratives of these two voices of the coloniser and the colonised, in such a way as to silence the voices of Indian women:

The Hindu widow ascends the pyre of the dead husband and immolates herself upon it. This is widow sacrifice. (The conventional transcription of the Sanskrit word for the widow would be sati. The early colonial British transcribed it suttee.) The rite was not practiced universally and was not caste- or class-fixed. The abolition of this rite by the British has been generally understood as a case of 'White men saving brown women from brown men'. White women-from the nineteenth-century British Missionary Registers to Mary Daly-have not produced an alternative understanding. Against this is the Indian nativist argument, a parody of nostalgia for lost origins: 'The women actually wanted to die.'45

The quotation from Spivak is, I believe, of very strong relevance to animal studies generally, the challenge of understanding anthropocentricism, and the problem of how violence renders its subject. It partly serves as a reminder that the ethical problem of animal suffering as we currently frame it has its limits and creates a logical structure that is difficult to escape. The politics of suffering-the insistence on determining if fish feel pain and shaping social and political responses only to the answer to this question-generates its own politics and its own subjectivities which become irrefutable. If pro-animal advocates explain that we want to save animals from suffering, or reduce the suffering of animals through welfare practices-if this is the only frame we have at our disposal-then we run the risk of being trapped within this truth, and more importantly, the animals we are trying to 'save' being trapped by this truth. This does not mean that we should not respond to violence, or that existing responses have no value; on the contrary, work by scholars and 
activists to highlight this suffering has been immensely successful in shaping public perceptions. However, even valuable responses participate in systems of truth that generate their own violence. Speaking of the value of the discourse of rights for women, Wendy Brown acknowledges the bittersweet attachment we can have to some emancipatory discourses, which both create relief from suffering yet, simultaneously, create the terms for continuing domination:

if violence is upon you, almost any means of reducing it is of value. The problem surfaces in the question of when and whether rights for women are formulated in such a way as to enable the escape of the subordinated from the site of that violation, and when and whether they build a fence around us at that site, regulating rather than challenging the conditions within. 46

Arguably animal advocates face this same dilemma with respect to improved welfare protections for animals aimed at reducing suffering. On one hand, at least with respect to land animals used for food, there have been tangible improvements in the conditions of containment and slaughter. However, a number of critics have pointed out that a reduction in suffering has not been accompanied by a reduction in use; on the contrary there has been an exponential global increase in the scale and intensity of animal utilisation for food. ${ }^{47}$ As Deirdre Bourke suggests, 'animal welfare legislation is often used not just to protect animals but also to regulate, and indeed facilitate, the ongoing use of animals'.48 Recent 'thought experiments' on the possibility of bioengineering livestock to not feel pain, only seem to further highlight the problem related to political and ethical claims that are solely based on the reduction of animal suffering as a goal. ${ }^{49}$ Just as Spivak might suggest there is an epistemic violence in imagining that the solution-the only solution-that Indian women wanted to the ritual practice of sati was to be saved by British colonisers, we might similarly ask if the only solution available to the problem of large-scale human utilisation of animals is to reduce or avoid suffering (to 'save' animals who suffer).

But it is the final sentence of that short quote from Spivak above that most intrigues me, and is relevant to both the epistemological problem of how we imagine what animals might want, and the significant challenge in imagining that animals may not want to be used for human benefit. Spivak describes the conservative Indian response defending ritual widow sacrifice with the short, ironic phrase: "The 
women actually wanted to die".' In observing that an 'Indian nativist' defence of sati effectively participated in reproducing the absurd logic that women wanted to die, Spivak mocks a patriarchal institutional practice that silences women in such a way that the only explanation for why women would consent to take part in the custom is the preference of death over life. The phrase 'the women actually wanted to die' is perfectly useable as a tool to understand the material and epistemic violence humans exert against animals, precisely because our epistemic framing of animals, and the monstrous systems of violence towards animals that exist all around us, appear to rely on a logic that 'the animals actually want to die' for our benefit and pleasures. Defenders of animal use explicitly endorse this messaging when they argue, for example, that animals used by humans enjoy a better life than they would if they were not used by humans. ${ }^{50}$ We find this logic powerfully present in at least some fishing practices, where fish are, as the official nomenclature used by the UN Food and Agriculture Organisation states, simply 'harvested' for human use from oceans, seas and rivers. ${ }^{51}$ In these cases we are presented with the idea of fish giving themselves passively to us to be used, with no particular preference as the whether they continue living or meet the end of life at our hands: 'the fish actually wanted to die.' Epistemic violence renders fish as uninterested in their own lives. However, we can see that the statement-'the fish actually wanted to die'-is absurd, precisely because it implies that fish lack any resistance to being used for our benefit and, like the fishing fantasy of fish throwing themselves onto the decks of boats, would prefer to die at our hands (or at least, have no preference whether they die or not at our hands). As I shall discuss later, it is precisely because of the possibility of offering a different framing, indeed the need to continually explore new framings, that it is important to conceptualise the possibility that animals, including sea animals, resist human utilisation and that they prefer not to be used, indeed they prefer not to die.52

\section{-CONCEPTUALISING ANIMAL RESISTANCE}

There has been some interesting scholarly work within animal studies on the question of animal resistance. Perhaps most prominent is the work of Jason Hribal, which documents, through historical case studies, examples of animals breaking free from human control-breaking down fences, escaping abattoirs, tussling with human controllers, maiming those who stand in their way. ${ }^{53}$ Hribal's method is to 
use historical information to construct narratives of animal resistance. For example, and relevant to my focus here on sea animals, Hribal narrates the successive acts of resistance by one of the orcas at Sea World, Tilikum (resistance that has since featured in the documentary BlackFish). ${ }^{54}$ In these cases, animal resistance is conceptualised as comprising intentional acts of insubordination against human domination. In some respects we have the resources to understand this sort of resistance by 'big fish' because it is part of the Western cultural imaginary. Herman Melville's Moby Dick, for example, was a similar story of a tussle between Captain Ahab and a white whale, a story effectively of domination and resistance. 55 Similarly Ernest Hemingway's The Old Man and the Sea enacts a narrative of human violence and animal resistance that resonates with a view of animal resistance as reflecting an intentional tussle against human domination. ${ }^{56}$ In both cases, it is clear that the animal would prefer not to die. I note that to an extent recreational fishing practices-that is, fishing for 'sport' where the intention is to catch fish for pleasure rather than food-rely on a conceptualisation of animal resistance to fuel human pleasure. It is precisely because fish resist in these cases that recreational fishing becomes a 'sport'; since the supposed pleasure and art of these fishing practices relies upon the capture of an animal who eludes the recreational fisher, and will struggle against the line when hooked (more on the hook itself below). ${ }^{57}$ The practice in recreational fishing of 'playing' the fish once they are hookedprolonging the period of time that the fish is on the hook so that they swim themselves to exhaustion trying get away-illustrates the extent to which fish resistance, or at least one understanding of fish resistance, as comprising acts of insubordination against human domination, is conceptually an important component of fishing. 58

Against the above conceptualisation of fish resistance, some may argue that fish cannot reasonably be said to 'resist' human domination in an intentional or 'agential' way. Indeed, at least two arguments could be made here against the above conceptualisation of resistance. One view might be that there is no 'scientific evidence' to suggest that fish, as intentional agents, work against human domination; that is, fish lack the reasoning (or other agential) capacity to choose to resist or subordinate human domination, and any visible evidence of what might look like resistance (for example, fish struggling at the end of a fishing line) reflects 
'instinctive' rather than 'rational' behaviour (this is, as I discussed above, a version of Descartes' animals-as-automatons view). It is certainly beyond the scope of this article to advance an empirically grounded argument for fish agency in relation to resistance based upon observational or similar studies, and, as discussed above, the epistemological problem of framing and conceptualising fish resistance might prevent the possibility of actually 'proving' (through observational studies or otherwise) that fish 'resist' in this way. If mainstay scientific empirical approaches cannot confirm the possibility of fish agency and cognition, then it becomes impossible to mount an empirically sound case that fish act in intentional ways to resist human domination, and we are condemned therefore, just as we are with the question of fish suffering, to wait for science to prove one way or another that fish, or at least most fish, might be able to resist. One solution for this is to rethink how we frame agency and its alignment with intentionality, as in Agnieszka Kowalczyk's suggestion that 'acts of resisting exploitation performed by non human bodies do not necessarily have to be thoughtful ... to be recognized as significant'.59 But as I will discuss below, we do not need to prove that fish exercise what we normatively might construct as 'agency' to understand that they resist human domination; this depends on the conceptual model of resistance we use.

There is a second, and I would suggest more sophisticated, version of the argument that animals, and hence fish, cannot be said to resist human domination. This argument suggests we have such intense systems of violence and containment applying to animals, that it is literally not possible for animals to resist in the sense of engaging in meaningful power relations. This view argues that since these forms of domination seem overwhelmingly one-sided and oriented to remove any possibility of escape, then there is no possibility of interaction or response. This is the view put forward by Clare Palmer in an early example of a discussion of animal resistance.60 Within the context of this discussion, Palmer follows a Foucauldian approach to argue that resistance is not possible for animals caught within intensive systems of domination. 'There is no relationship ... All spontaneity and almost all communication is removed from our brutal encounter. Thus it cannot be a power relationship.' 61 Resistance, in this view, is only possible where entities subject to violence have some means of response or reaction to engage with relations of 
power. Where there is no perceived freedom to move by the victim of violence, there is no possibility of power.

Against the view put forward by Palmer, I would suggest that it is possible to imagine resistance if we focus on the instrumentation of violence used to dominate animals, and the way in which these apparatuses effectively work against the active resistance of animals, even if, from the outside, these relations appear to involve no contest or be unilaterally one-sided in character. In an important essay, Tim Ingold reminds us that violence always aims to put down and contest resistance. ${ }^{62}$ Indeed, the technologies of violence would not be used if the objects of violence were not autonomous or had not evaded capture and utilisation in the first place:

Consider the slave-driver, whip in hand, compelling his slave to toil through the brute infliction of severe pain. Clearly the autonomy of the slave in this situation to act according to his own volition is very seriously curtailed. Does this mean that the slave responds in a purely mechanical way to the stroke of the whip? Far from it. For when we speak of the application of force in this kind of situation, we impute to the recipient powers of resistance-powers which the infliction of pain is specifically intended to break down. That is to say, the use of force is predicated on the assumption that the slave is a being with the capacity to act and suffer, and in that sense a person. And when we say that the master causes the slave to work, the causation is personal, not mechanical: it lies in the social relation between master and slave, which is clearly one of domination. In fact, the original connotation of 'force' was precisely that of action intentionally directed against the resistance of another sentient being. ${ }^{63}$

This understanding of resistance treats instruments of violence, and their technological development, as intimately related to the forms of resistance that they encounter in their target. Here, the resisting body generates the need for the instrument of violence, and technological refinement in the instrumentation of violence corresponds with the continuing creativity and innovation of those who resist.

This view of resistance as generated by, and working intimately against, systems of production correlates with what I would describe as an 'autonomous' or operaist model of resistance. In understanding this model of resistance, I have been 
influenced by both the Italian Marxist operaist tendency, and by the more recent work of Fahim Amir, who explores operaism as way to explain animal subordination in systems of production. ${ }^{64}$ In this view, systems of production and exchange, such as capitalism, suck the productive capacities and creativity of the bodies that labour within these systems. This is essentially a parasitic relation, where resistance is captured and redeployed through systems of subordination. 65 Here, even extreme forms of domination that appear to lack any movement or resistance are in fact the product of active forms of creative resistance by those who are subordinated; a resistance that is subsequently coopted in the process of domination. Thus, the means used to restrain and intensively dominate animals are themselves a product of the active forms of resistance employed by animals towards human instrumentalisation. This autonomous or operaist model of resistance dynamically re-understands the way production occurs so that systems of domination must keep pace with new forms of resistance to extract productivity (this is part of the process of 'subsumption' inherent to production).66 For example, as Michael Hardt and Antonio Negri have argued, the novel flexibilities in workplaces that characterise post-Fordist production (flexible work hours, work from home arrangements, teleworking and so on) are the result of capitalism adapting to the resistance of workers to Fordist modes of disciplined production. It is because workers actively dropped out of labour through absenteeism, through cultural experimentation, through everyday sabotage, that capitalism needed to adapt and re-mould work itself to maintain productivity.67 Here resistance is always present, but it only becomes apparent where there is organised confrontation; without this there is an apparently seamless view of production, where those who are subject to intense forms of domination and discipline appear to be working cohesively with the production apparatus. As Mario Tronti observes:

Workers' struggles determine the course of capitalist development; but capitalist development will use those struggles for its own ends if no organized revolutionary process opens up, capable of changing that balance of forces. It is easy to see this in the case of social struggles in which the entire systemic apparatus of domination repositions itself, reforms, democratizes and stabilizes itself anew. 68 
We might apply this autonomist view of resistance to understanding the relationship between emerging technological and production processes and confrontation in the context of animal containment, breeding and slaughter. One example of this is the curved corrals used in slaughterhouses. ${ }^{69}$ The introduction of curves into the chutes or races that led cattle towards death minimised the possibility of an animal responding to the chute by balking and backing up. ${ }^{70}$ In so far as the curves work to smooth the process of slaughter and work with (rather than against) animal movement, these curved corrals directly respond to, and 'lubricate' animal resistance. ${ }^{71}$ I should be clear here that this cooption of resistance need not lead to outcomes that increase the suffering of animals; quite the reverse. Working to counter resistance in this sense can work to promote enhanced welfare outcomes; the curved corals arguably reduce the suffering of animals before death (suffering at least with respect to stress, and the cognition and anticipation of the death to come). However, the curves also function to manage resistance and enable the smooth process of slaughter, maximising the efficacy of human utilisation. Bodies shape productive processes, while production shapes bodies; in this sense the 'agency' of animals (as at least as resistive agents) is generated as a political subjectivity. Hardt and Negri state: 'The great industrial and financial powers thus produce not only commodities but also subjectivities. They produce agentic subjectivities within the biopolitical context: they produce needs, social relations, bodies, and minds-which is to say, they produce producers.' 72

In some respects, thinking about resistance in this way is a different sort of 'relational approach' to thinking about how we engage with animals. 'Relational approaches' are currently enjoying much interest within the field of human animal studies, through a range of perspectives such as those offered by Clare Palmer, John Law (discussed below), Donna Haraway and Elspeth Probyn.73 At least some of these approaches quite explicitly question 'dualistic' accounts of human animal relations - such as animal rights accounts which emphasise one-sided domination of animals by humans-by focusing upon forms of shared relationality and working, where animals and humans 'co-shape' each other and might derive mutual benefit from their relationships. ${ }^{74}$ The view I advance here differs from these approaches in so far as I argue that conflict is the starting point for thinking about relationality: we are in relation with animals, but this is a relation essentially of hostility. As I argue in 
the conclusion below, this conflict need not be thought of as a dead end, but can comprise a potential beginning for different (and hopefully less violent) relationalities.

—THREE TECHNOLOGIES: HOOK, PURSE SEINE, AQUACULTURE

Building on this conceptualisation of resistance, I would like to offer three examples of how we might conceptualise fish resistance, through a focus on three technologies used to capture, utilise and slaughter fish: the hook, the purse seine and aquaculture. This identification of technologies conforms to the autonomous or operaist view of resistance I have described above. All these examples are framed by the understanding that these technologies aim precisely to counter and put down resistance; as such, the technology itself tells us something about the active politics of restraint and resistance involved in fishing practices, without having to demonstrate that fish display normatively defined intentionality and agency.

Hook

The hook is possibly one of the oldest human technological innovations for the capture of animal life. ${ }^{75}$ This technological development allowed sea animals, which otherwise evade capture, to be hunted just as land-based animals were also hunted. Describing evidence of 100,000-year-old human remains at the Klasies River Mouth caves in Africa, Richard Klein and Blake Edgar observe that it is probable that these people avoided confrontation and risky hunting practices:

the people tended to avoid confrontations with the more common-and more dangerous-buffalo to pursue a more docile and less common antelope, the eland. Both buffalo and eland are very large animals, but buffalo stand and resist potential predators, while eland panic and flee at signs of danger. ${ }^{76}$

They also suggest there is little evidence of fishing among these people who dwelled near the water, reflecting a 'difference of technology' compared to later humans. Fish resist differently to buffalo: they evade capture, they are elusive. It is only when fishing gear is developed that it becomes feasible to counter this resistance:

only the more recent sites contain probable fishing gear like grooved stones for weighting nets or lines and carefully shaped toothpick-size bone 
splinters that could have been baited and tied to lines like hooks. In short, only the more recent people undeniably possessed the technology for fishing. ${ }^{77}$

In this sense the hook is one of the technological innovations which shifted the nature of human hunting practice, and opened the sea as a 'commons' for the human pursuit of animal based food. ${ }^{78}$ Forbes magazine recently listed the hook as one of the twenty most important tools invented. ${ }^{79}$

The hook would not be necessary if fish allowed themselves to be passively 'harvested'. On the contrary, it is precisely because fish elude human capture that the hook was devised. The fish hook is an ingenious capture and kill device. ${ }^{80}$ It is a sharp point with a bend in it, which can be affixed to a line, allowing its operator to work at a distance. The bend is crucial, in so far as the hook aims to not merely impale its recipient, but to snag the body of the fish to the hook, allowing it to be drawn in by a line. The hook frequently works with a lure or bait. In these cases, the hook is a stealth device; it aims to deceive an animal who would evade capture by other means. The hook was thus fundamentally conceived to work against fish resistance to capture. Elaine Scarry, in her classic study of torture, The Body in Pain, points out that the most ingenious torture devices use the body of the victim against itself.81 The fish hook is no different. When it finds sinuous flesh with which to impale itself on and bind itself to, the body of the fish is effectively turned against the self; the fish will struggle against its own mouth (or elsewhere-the gut, the eye) which has been caught by the hook, sometimes deepening the hold of the hook on the flesh. ${ }^{82}$ The technical innovation of the barb in the hook-a counter facing spur near the point-heightened the capacity of the hook as a technology to refuse resistance. The barb makes it more difficult for a fish to free themself once impaled; freedom from the hook is only possible through further laceration.

The discussions that are presently occurring within the recreational-'catch and release'-fishing community on whether barbless hooks should be used on ethical (and sustainability) grounds are interesting in this regard. ${ }^{83}$ Recreational fishing, as I have stated, derives its supposed pleasure from the resistance of fish to capture. Recreational fishing is not interested in merely impaling fish, but the whole process of drawing in a struggling fish, and then, if the animal survives, setting it free. The barb in the hook offers an additional safeguard against the fish slipping 
away once impaled; however, it risks further injury or death to the fish, particularly if the fish is impaled in the gut, working against the stated aim of recreational fishing to merely catch and return fish as sport. In some respects it should be no surprise that hook development can work to maximise resistance to enhance the 'sport' of fishing. For example, 'circle hooks' incorporate a wider curve to more efficiently facilitate sport fishing; this 'unique hook shape causes the hook to slide toward the point of resistance and embed itself in the jaw or in the corner of the fish's mouth. The actual curved shape of the hook keeps the hook from catching in the gut cavity or throat.'84 The Florida Sea Grant research circular I quote from here goes on to explain that 'fish hooked in the corner of the mouth or jaw tend to fight better than fish that are hooked in the gut.' 85 Here, resistance itself, maximising the intensity of resistance, making it persist, is the objective of productive activity, its raison d'être. On one hand recreational fishing tells us a lot about the sorry state of fish welfare, and the limited impact welfare considerations or the possibility of fish suffering have upon some fishing practices. On the other hand, though, it tells us something about the investment recreational fishing has in fish resistance, since this practice is only deemed productively pleasurable (for the fisherperson) if the fish remains bound to the line until the fisherperson releases it, even if this process of struggle and resistance leads to the unplanned death of the fish itself.

\section{Purse seine}

The net is another innovation in fish capture and, like the hook, it has a long history of human use.86 The net is a discriminating capture device, at least in some respects: the use of rope or twine in a mesh pattern allows water and small creatures to move through the device, while ensnaring larger target fish. In relation to mechanised fishing, there has been a great degree of focus on the environmental impacts of netbased fishing, particularly trawling (where a net is pulled through the water at speed) and the lack of discrimination in net fishing with respect to particular 'high value megafauna' who are caught as 'by-catch' (such as dolphins). ${ }^{87}$ Like the hook, the net is a technological innovation designed to capture animals that would otherwise evade capture. As I have stated, net fishing is an old technique of human hunting; today, industrialisation has mechanised this practice of predation to massively increase its efficiency. Trawl netting, for example, frequently uses 
motorised speed and net breadth and depth to run down groups of fish in the water; fish will swim themselves to exhaustion before they finally surrender to the net. ${ }^{88}$

An example of a net that is commonly used within industrialised wild fish capture, and a technology that works to counter the resistance of fish, is the purse seine. ${ }^{89}$ The purse seine is like a large drawstring bag. A large net-which can be up to a kilometre long and two hundred metres deep-is threaded over an area, and then pulled inwards to trap the animals within. This method is very different from trawl fishing. Rather than using sheer speed to capture fish, the purse seine uses stealth to encircle them. Decoys can be part and parcel of the fishing operations; for example, floating objects, or 'fish aggregating devices' (FADs), which attract fish, can be used to congregate fish before the purse seine is used. ${ }^{90}$ The net technology can work to selectively target species: 'the geometry of the net during the set is also significant for understanding the vertical dimension of the operation, and the volume enclosed, which may determine which schools and individuals are captured'. 91

This sort of industrial-scale net fishing can generate immense welfare concerns. For example, when the net is drawn in, many fish will die as they are crushed by other fish on top of them. Here, fish resistance can be used directly to facilitate human intention. As the net is drawn in, fish will thrash and struggle. The closing encircling space means that fish will come into violent contact with other fish, and many fish will injure or kill themselves in this process. ${ }^{92}$ One practice in industrial purse seine fishing is to progressively close the net and allow fish to struggle and injure each other as the compression by the net increases (this is why blood will surface on the water as the net constricts). ${ }^{93}$ A pump or a 'brailer' (a smaller scooping net) is then used to extract fish nearer the surface, many of whom may be injured or already dead. Once these fish are pumped or brailed onto the ship, the net is tightened further, and the process begins again. Fish resistance, against the prospect of their own death, is here subsumed and utilised as a means to facilitate human productivity in wild fish capture.

Purse seine fishing is another example of how we might conceptualise fish resistance in relation to technological innovation. The purse seine, like the hook is an ancient technology. But it is used with contemporary technologies: helicopters used to search out fish schools, mechanised sea transport including speed boats 
designed to string the encircled area, the Puretic Power Block which is capable of hauling large nets in to the boat, the pump which can smoothly extract fish from the water directly to ice slurries below deck. ${ }^{94}$ These technologies are accompanied by techniques which are refined year after year to more efficiently capture fish; for example, the use of floating devices, or the use of the compression and pump technique I have already described. These techniques and technologies all aim to counter resistance; their promise of improved efficiency relates to their ability to capture entities that evade and resist capture.

\section{Aquaculture}

Commercial wild fishing is in some respects a form of hunting. ${ }^{95}$ It operates today as a peculiar industrial form of mechanised predation. In this respect, commercial fishing is unlike any other large-scale form of animal utilisation for food by humans. Industrialised 'farm'-based domestication dominates the production of land animals for human consumption, but mechanised hunting of 'wild fish' remains the main way most of the globe obtains fish for food. In so far as fish numbers in the wild are abundant enough to sustain this sort of hunting industry, at least at present, and, simultaneously, the evolved techniques and technologies for wild fishing are effective enough (that is, effective in countering fish resistance to them), this sort of predation on a large scale remains economically viable.

However, as I have stated above, over the last twenty years there has been an extraordinary explosion in the development of aquaculture which has substantially shifted the nature of large-scale fishing industries. In some respects, the development of aquaculture is itself a technological response to fish resistance. We know that since the 1980s the number of wild fish caught on a global level has more or less stayed the same. ${ }^{96}$ It is aquaculture that has filled the gap in supplying the remaining fish used for human consumption. On one hand, there is an environmental explanation for this: as experts have repeatedly warned, wild fishing is at capacity or being actively over exploited for many fish species. However, this perspective assumes that fish are merely passive objects that must be found and 'harvested' (that is, the epistemic problem I referred to above). A different way to conceptualise this is to see that the human technical means for capturing wild fish through mechanised hunting technologies have reached their limit. The economics 
are poor in terms of trying to hunt the remaining fish who currently evade capture, and because of these hunting activities fish are not able to 'replenish' themselves through reproduction to meet growing human demand for food. (Certainly, we know that regulatory controls have had a limited effect in preventing wild fish exploitation on a global level..) ${ }^{97}$ Economic realities associated with trying to capture evasive animals who are scarce, depleting and evade capture, must surely drive the viability of other options, including intensive farming. Thus more concentrated forms of utilisation, such as aquaculture, have become economically viable. In this sense, fish resistance has had a role to play in the development of aquaculture on a global scale. Wild fish are not just scarce because humans cannot find them; they are scarce because they evade capture. Aquaculture solves this problem by 'domesticating' fish into enclosed 'farms'. Domestication is a solution to animal resistance that has been effectively applied to land animals over millennia. ${ }^{98}$ It is now being applied in earnest to fish.

The rise of aquaculture need not produce poorer outcomes for fish welfare. Certainly it is conceivable that welfare provisions could improve as a result. For example, there is more scope to use relatively 'quick' stun and kill methods, such as individually stunning fish with a blow or spike, or using new techniques such as electrocution. In so far as health outcomes are considered important for welfare, aquaculture provides opportunities to prevent diseases and injury through concentrated management.

But there is a complex story of resistance and power that accompanies the development of techniques in aquaculture, including those oriented towards improved welfare. Aquaculture holds the promise of mitigating the effects of fish resistance on a day-to-day level through concentrated forms of control. This is because, like other factory farms, aquaculture provides operators the opportunity to exert birth-to-death controls to enable a more refined management of the final product. Perhaps tellingly, one expert comments: 'the entire life cycle has been rigorously controlled. We know where it was born, where it died, and what it ate throughout its entire life.' 99 One area of innovation is being able to control for parasites and diseases through immunisation; another is exerting more control over size and quality of meat offered for sale, enabling production of a more consistent homogenised end product.100 This does not mean that aquaculture fish lack the 
capacity to resist this overwhelming system of control; on the contrary, aquaculture attempts to manage the movement of populations that are themselves elusive, and thus represents a concentrated attempt to deal with fish resistance. As John Law has noted about salmon farms, despite the intensity of the farming methods fish within aquaculture environments defy systems of control and detection:

The salmon in the pen are more or less invisible. Sometimes you can see what's going on, but most of the time you can't. Instead, all that you can see is a few dozen salmon out of 50,000. This is the paradox. Even though they are being controlled, the salmon are also dissolving themselves into invisibility. So this is the argument. If salmon are animals this is precisely because in relation to human beings they are also elusive. Down there in the water, so far as the people are concerned, they are also doing their own sweet salmon thing. ${ }^{101}$

This does not mean, like in other systems of animal based production, that creative resistance cannot be captured. In line with the 'autonomous' view of resistance I have advanced here, we can also identify a range of techniques and technologies that capture and use the autonomy of fish themselves. Consider current experiments on the use of lights in aquaculture pens to control behaviour. Some intensively farmed fish will exhibit fin damage as a result of inter-fish aggression, and abrasion against surfaces; problems which may not occur in the wild. In some cases, this is a reflection of the relative 'stocking densities' within aquaculture environments. 102 The problem is exacerbated where fish congregate and do not spread out evenly within the available space in sea cages, as is the case with salmon. Various researchers have experimented with using underwater lamps to influence the behaviour of salmon and prevent congregation, thus helping to mitigate the problems associated with high density. ${ }^{103}$ These techniques work to shape the responsiveness of fish to the environment of the sea cage. The light techniques capture fish responses-such as aversion to bright light—and channel behaviours to improve the efficiency of production techniques. Turn on a light, and some fish will run away: this technique thus uses fish resistance and autonomy to prevent fish congregating and to improve the quality of the meat produced. Creativity and resistance are channelled to create docile bodies out of resistant bodies; that is, they 
mould fish to use the production space in ways which do not compromise the quality of stock.

In some cases, intensive techniques use the bodily processes of the animal itself as a way to achieve production efficiency. Consider how farmed fish are routinely starved before transport and slaughter.104 In some cases, farmed fish are denied food for several days or weeks. Fish are 'ectothermic' and thus have metabolic efficiency in food consumption; many fish routinely survive in the wild for long periods without food. Aquaculture producers make use of this quality in starvation techniques; they take advantage of reduced metabolism, and the fact that fish empty their guts and faeces, thus enabling a more desirable end product.105 Of course, the welfare picture here is not straightforward. Some argue that the diminished metabolism induced by starvation is beneficial to welfare, for example, by reducing aggressive behaviours. ${ }^{106}$ In these cases, however, we find again that the creative energies of fish, including their own resistance-at least at the level of a will to survive-is captured by the production process and harnessed towards the ends of production. Production in this sense is a process of interaction between humans and fish, of which innovation in relation to fish resistance drives innovation in production towards human ends. 107

\section{-CONCLUSION}

I would like to conclude with a few short observations on the conceptualisation of fish resistance and the potential it has for thinking about how we might intervene in systematic human violence against animals. Firstly, I stress that I am not arguing that we need to abandon a welfare approach to considering the treatment of fish. It is certainly worth noting that although progress in fish welfare has been relatively modest, at least relative to land animals that are used by humans, there have been some positive steps. ${ }^{108}$ In principle, advocates for improving welfare for fish should support any reforms that reduce the suffering experienced by fish as part of the process of human utilisation. Questions around welfare will arguably become more vexing as consumption of fish sourced through aquaculture proportionally increases on a global scale. The inevitable growth of aquaculture industries will pose a mixture of opportunity and danger for animal advocacy. On the one hand, we are more likely to be able to control and regulate for welfare outcomes for factory 
farmed fish than for wild commercial fishing, simply because the fish in aquaculture are subject to around-the-clock controls and there is the possibility of enhanced management of pre-slaughter and slaughter conditions. On the other hand, as with factory farmed land animals, I can only imagine that we are likely to see the intensity of our use of fish escalate, where economies of scale will work at cross purposes with welfare outcomes and new horrors are introduced as fish are exposed to intensive mechanised large-scale production systems.

It is for the latter reason that I think there is promise in exploring new ways to conceptualise the problem of human use of animals and an urgent need to develop new framings. As I have argued, if we can understand fish as subject to large-scale systems of violence, and understand fish as resistant to these same systems of violence, then this offers one way to imagine social justice for animals that goes beyond relief from suffering and towards relief from human-imposed violence. This perspective asks us to imagine fish as not merely beings who might suffer, but beings who would prefer not to be used and would prefer not to die, beings who actively resist human attempts to bend them towards those ends. Adopting this sort of perspective offers opportunities to at least shift some of the language that is commonplace about fish and fisheries. For example, a different epistemological framing might allow us to be rid of the pernicious concept that fish are passive objects 'harvested' from oceans and rivers. Further, the framing of fish as resistive animals might similarly be able to shift a public perception towards understanding technologies associated with fishing-the hook, the net, the fish farm-as instruments specifically designed to deliver violence (that is, 'weapons') upon creatures who would rather not receive this violence. Importantly, the question of whether fish suffer is not central to understanding whether fish resist. Whether fish feel pain might have important implications for weighing the gravity of the violence we impose on sea animals as a social justice issue, but it does not alter the reality that violence is being imposed, and that there are creatures who resist this violence.

Finally, and perhaps this is a more obscure point, acknowledging fish resistance inevitably involves rendering fish as co-creators (often unwilling co-creators) of the world we live in. Our systems of violence directed towards fish-the long food supply chains that link ocean or fish farm to dinner plate-owe something to fish resistance, since industries and economies have been created out of countering this 
resistance. This is both a sobering and empowering way to conceptualise the problem of fish resistance. It is sobering because so much potential creativityhuman and non human-has been channelled into so much violence; this is violence that many animal advocates are increasingly arguing is unnecessary. It is, however, empowering to consider fish resistance in this way because understanding that fish might resist offers us a way to comprehend the immense contribution of non-human political agency to the world that we see around us. Our world would be unrecognisable without all the animals that have been willing and unwilling cocreators in our pasts; but this simultaneously offers us a way to think about how much our world would change if we cultivated a different relationship with the animals who will be in our future. In a discussion on the value of considering resistance and its usefulness for thinking about political structure and change, Hardt and Negri state:

Now, it is perfectly reasonably to ask if it is in fact true that resistance comes before power and that social struggle precede and prefigure capitalist restructuration. We have not offered an argument for it, reallyprecisely, we have treated it as an axiom. Our book tries to demonstrate that it is plausible to read the history from below, but that is really not a proof. What is more interesting, though, is the political effect of this axiom, that it highlights the power of resistance and the power of social struggles ... Today, when facing the forces of capitalist globalisation and our new world order, it is all too easy and all too common to feel ourselves and our social movements powerless. This method can work as a kind of antidote to that cynicism and sense of powerlessness. It is not a matter of pretending that we are powerful when we are not, but rather recognising the power we really have; the power that created the contemporary world and can create another. 109

Fish create worlds we cannot even understand; they defy our imagination. Our primary relationship with fish, at least so far, has been violent and parasitic. We have quite literally fed off their creativity for our own benefit. Recognising fish resistance might give us different ways to think about how we might relate to fish beyond simply finding new ways to counter their resistance to us. What would our 
world look like if we worked with and supported the creativity of fish, rather than simply working against it?

Dinesh Joseph Wadiwel is a lecturer in social justice and human rights at the University of Sydney. His research interests include sovereignty and the nature of rights, violence, race and critical animal studies. His most recent monograph is The War against Animals (2015).

\section{-Notes}

1 This article is based on a public lecture delivered at the Human Rights and Animal Ethics Research Network, University of Melbourne, December 2014. My sincere thanks are owed to a number of scholars who offered thoughts and engagement in the development of the article, including Siobhan O’Sullivan, Clare McCausland, Matthew Chrulew, Sue Donaldson and Rhiannon Galla.

2 See, for example, Food and Agriculture Organization of the United Nations, FAOSTAT, 2010 data, at $<$ www.faostat.fao.org>.

3 Alison Mood, Worse Things Happen at Sea: The Welfare of Wild-Caught Fish, Fishcount.org.uk, 2010, p.

71. See also Peter Singer, 'Fish: The Forgotten Victims on Our Plate', The Guardian, 14 September 2010, at <http://www.theguardian.com/commentisfree/cif-green/2010/sep/14/fish-forgotten-victims>.

${ }^{4}$ Alison Mood and Phil Brooke, 'Estimating the Number of Farmed Fish Killed in Global Aquaculture Each Year', Fishcount.org.uk, 2012, p. 1.

5 Food and Agriculture Organization of the United Nations, 2010 data.

${ }^{6}$ There have been some attempts to quantify the numbers of fish caught through recreational fishing in localised studies. See for example C.B. Smallwood, K.H. Pollock, B.S. Wise, N.G. Hall and D.J. Gaughan, Quantifying Recreational Fishing Catch and Effort: A Pilot Study of Shore-based Fishers in the Perth Metropolitan Area, Fisheries Research Report no. 216, Final NRM Report-Project No. 09040, Department of Fisheries, Western Australia, 2011.

7 Food and Agriculture Organization of the United Nations, The State of World Fisheries and Aquaculture, 2014, Food and Agriculture Organization of the United Nations, Rome, 2014, p. 3. 8 Food and Agriculture Organization of the United Nations, The State of World Fisheries and Aquaculture, 2014, Food and Agriculture Organization of the United Nations, Rome, 2014, p. 7.

9 Paul J. Crutzen, 'Geology of Mankind', Nature, vol. 415, 2000, p. 23. See also P.J. Crutzen and E.F. Stoermer, 'The "Anthropocene"', Global Change Newsletter (IGBP), no. 41, 2000, pp. 17-8. 
${ }^{10}$ Food and Agriculture Organization of the United Nations, The State of World Fisheries and Aquaculture, 2014, pp. 6, 19.

11 Michael Marshall, 'Farmed Fish Overtakes Farmed Beef for First Time', New Scientist, 19 June 2013, <http://www.newscientist.com/article/dn23719-farmed-fish-overtakes-farmed-beef-for-firsttime.html\#.VLSaUiuUeP8>.

${ }^{12}$ See Celeste Black's excellent summary: Celeste Black, 'The Conundrum of Fish Welfare', in Peter Sankoff, Steven White, Celeste Black (ed.), Animal Law in Australasia: Continuing the Dialogue 2nd edn, Federation Press, Sydney, 2012, pp. 245-63.

${ }^{13}$ See, for example, Fisheries Society of the British Isles (FSBI), Fish Welfare, Briefing Report 2, 2002;

Animals Australia, 'Fishing,' Animals Australia, <http://www.animalsaustralia.org/issues/fishing.php>; P.J. Ashley, 'Fish Welfare: Current Issues in Aquaculture', Applied Animal Behaviour Science, vol. 104, 2007, pp. 199-235. doi:10.1016/j.applanim.2006.09.001; Mood, Worse Things Happen at Sea; Australian Animal Welfare Strategy, Commercial Capture Fishing Guidelines, <http://www.australiananimalwelfare.com.au/content/aquatic-animals/commercial-capture-fishingguidelines $2>$.

${ }^{14}$ B.M. Poli, G. Parisi, F. Scappini, G. Zampacavallo, 'Fish Welfare and Quality as Affected by PreSlaughter and Slaughter Management', Aquaculture International, vol. 13, 2005, pp. 29-49.37. doi: 10.1007/s10499-004-9035-1.

15 Ibid., p. 38. These are all observed stunning periods; however, there is great variation, and a wealth of anecdotal information suggests some fish endure many hours of asphyxiation.

16 Fishcount.org.uk, 'Humane Slaughter', Fishcount.org.uk, <http://fishcount.org.uk/fish-welfare-incommercial-fishing/humane-slaughter>.

17 Poli, Parisi, Scappini, Zampacavallo, p. 39.

18 Ibid., p. 38.

${ }^{19}$ Ashley.

20 See Black.

${ }^{21}$ In the case of Australia, this includes state-based legislation such as the NSW Prevention of Cruelty to Animals Act 1979, and the Australian Animal Welfare Strategy. Welfare approaches have their limits and have been subject to strong criticism from some animal advocates and scholars. For example, anticruelty legislation includes numerous exceptions for particular animals, and exempts certain actionssuch as killing-from an understanding of 'cruelty'. As Malcolm Caulfield notes, 'killing an animal is not per se a cruel act'. See Malcolm Caulfield, Handbook of Australian Animal Cruelty Law, Animals Australia, Sydney, 2008, p. 139.

22 This is the utilitarian balancing act that is central to welfare considerations. See John Webster, 'Farm Animal Welfare: The Five Freedoms and the Free Market', Veterinary Journal, vol. 161, no. 3, 2004, pp. 229-37. doi: 10.1053/tvjl.2000.0563.

${ }^{23}$ Animals Australia's web page on fishing is one example of this. Animals Australia state: 
Fishing is considered a recreational past-time among most Australians and Australia has a large commercial fishing fleet. Any animal protection group that raises the issue of fish welfare in this country is instantly derided. Having to acknowledge that fish feel pain and distress is not something that those who enjoy fishing, or those whose income is generated through fishing, want to know about. As an animal protection organisation, Animals Australia's role is to present facts that will allow the community to make informed choices- whether they be fishermen (or women) or those who eat fishknowing that many members of the community if informed, will make personal choices that do not cause harm to others. Therefore, the fact that fish feel pain and distress is just another inconvenient truth that needs to be told.

See Animals Australia, 'Fishing: Can They Suffer? Do They Feel Pain? Understanding the Creatures of the Marine Kingdom', Animals Australia Website,

<http://www.animalsaustralia.org/issues/fishing.php>.

24 Sneddon states: 'Administering morphine significantly reduced the pain-related behaviours and opercular beat rate and thus morphine appears to act as an analgesic in the rainbow trout. It is concluded that these pain-related behaviours are not simple reflexes and therefore there is the potential for pain perception in fish.' See Lynne U. Sneddon, 'The Evidence for Pain in Fish: The Use of Morphine as an Analgesic', Applied Animal Behaviour Science, vol. 83, no. 2, 2003, pp. 153-62. doi:10.1016/S0168-1591(03)00113-8. See also L.U. Sneddon, V.A. Braithwaite and M.J. Gentle, 'Do Fish Have Nociceptors?: Evidence for the Evolution of a Vertebrate Sensory System', Proceedings of the Royal Society London Series B, vol. 270, no. 1520, 2003, pp. 1115-21. doi: 10.1098/rspb.2003.2349; and V.A. Braithwaite and F.A. Huntingford, 'Fish and Welfare: Can Fish Perceive Pain and Suffering?' Animal Welfare 13, 2004, S87-S92. I have left aside here emerging research on fish emotion and intelligence. See for example Culum Brown, 'Fish Intelligence, Sentience and Ethics', Animal Cognition, 18.1, 2015, pp. 1-17. doi: 10.1007/s10071-014-0761-0.

25 V.A. Braithwaite, Do Fish Feel Pain? Oxford University Press, Oxford, 2010.

26 On this, see John Cottingham, 'A Brute to the Brutes? Descartes' Treatment of Animals', Philosophy, vol. 53, 1978, pp. 551-9.

27 J.D. Rose, R. Arlinghaus, S.J. Cooke, B.K. Diggles, W. Sawynok, E.D. Stevens, C.D.L. Wynne, 'Can Fish Really Feel Pain?', Fish and Fisheries, vol. 15, no. 1, 2014, pp. 97-133, doi: 10.1111/faf.12010. See also J.D. Rose, 'The Neurobehavioral Nature of Fishes and the Question of Awareness and Pain', Reviews in Fisheries Science, vol. 10, no. 1, 2002, pp. 1-38. doi: 10.1080/20026491051668. Recently Brian Key has provided another defence of the view that fish do not feel pain. See Brian Key, 'Why Fish Do Not Feel Pain', Animal Sentience, vol. 1, no. 3, 2016, <http://animalstudiesrepository.org/animsent/vol1/iss3/1/>. See also my response, Dinesh Wadiwel, 'Fish and Pain: The Politics of Doubt', Animal Sentience, vol. 1, no. 3, <http://animalstudiesrepository.org/animsent/vol1/iss3/31/>. 
28 Black, pp. 250-1. At its most disturbing, the lack of consensus on fish suffering allows for the continuation of recreational and industrial fishing practices that are based upon generating human pleasure through the unpleasure of the animals we use. It is perhaps telling in this respect that recreational fishers welcomed the Rose et al. study. Martin Salter, writing for Fishing World, exclaimed: 'Anglers will never be free from the "don't fish feel pain?" question which has been in the news again lately_but in a good way, thanks to some excellent work by the American Professor James Rose. If you ever run into this guy buy him a beer.' See Martin Salter, 'Fishos Buoyed by 'Fish Pain' Study', Fishing World, 24 January 2013, < http://www.fishingworld.com.au/news/blog-fishos-buoyed-by-fish-painstudy>. In this context, see also my own discussion on pleasure and unpleasure in relation to human sovereignty over animals, Dinesh Joseph Wadiwel, The War against Animals, Brill and Rodopi, Leiden and Boston, 2015, pp. 21-9.

${ }^{29}$ Sue Donaldson and Will Kymlicka, Zoopolis: A Political Theory of Animal Rights, Oxford University Press, Oxford, 2011, p. 2.

30 Peter Singer, Animal Liberation, Jonathan Cape, London, 1975. See also Peter Singer, 'Speciesism and Moral Status', Metaphilosophy, vol. 40, nos 3-4, 2009, pp. 567-81. doi: 10.1111/j.1467-

9973.2009.01608.x. Tom Regan, The Case for Animal Rights, University of California Press, Berkeley, 1983. See Martha C. Nussbaum, Frontiers of Justice: Disability, Nationality, Species Membership, Harvard University Press, Cambridge, MA, 2006 and Martha C. Nussbaum, 'Beyond 'Compassion and Humanity', in Cass R. Sunstein and Martha C. Nussbaum (eds), Animal Rights: Current Debates and New Directions, Oxford University Press, Oxford, 2004, pp. 299-320.

31 Michel Foucault, The History of Sexuality Volume 1: The Will to Knowledge, Penguin Books, London 1998, p. 93. Note resonances with Max Weber's definition: “Power" (Macht) is the probability that one actor within a social relationship will be in a position to carry out his own will despite resistance, regardless of the basis on which this probability rests.' See M. Weber, Economy and Society: An Outline of Interpretive Sociology Volume 1, Bedminister Press, New York, 1968, p. 53. The difference between this conception of power and that of Foucault is that in the latter model the 'will' of an individual has no bearing on the production of power. Our own 'will' is itself a product of the relation of power that we are caught in-effects of power are rarely the product of intention. I note further that Foucault notoriously amends his view of resistance, or at least offers different perspectives on resistance, particularly in the context of his later work. It would be incorrect to say that resistance does not matter in his late work; on the contrary, we find the problem of resistance revisited in different forms. For example, Foucault has a lengthy discussion of the concept of 'counter-conduct' a mode of resistance against governmental regimes, in his 1977-78 lectures. See Michel Foucault, Security, Territory, Population: Lectures at the Collège de France, 1977-78, Palgrave Macmillan, London, 2007, pp. 194-5. Foucault's late lectures contain a useful summary of his own methodological trajectory. See, particularly, Michel Foucault, The Government of Self and Others: Lectures at the Collège de France 1982- 
1983, Palgrave Macmillan, New York, 2010, pp. 4-6; and Michel Foucault, The Courage of Truth: Lectures at the Collège de France 1983-1984, Palgrave MacMillan, New York, 2011, pp. 8-9.

32 Foucault, The Will to Knowledge, p. 96.

33 See Dinesh Joseph Wadiwel, 'Lubricative Power', Theory and Event, vol. 12, no. 4, 2009. doi: 10.1353/tae.0.0090.

34 See Black, pp. 245-6.

35 In this essay I explicitly build on the conceptualisation of epistemic violence and resistance that I offer in my book, The War against Animals.

${ }^{36}$ See Foucault's famous closing paragraphs in The Order of Things. Michel Foucault, The Order of Things: An Archeology of the Human Sciences, Vintage Books, New York, 1994, pp. 386-7.

37 Ibid., p. xxii.

${ }^{38}$ Rose, Arlinghaus, Cooke, Diggles, Sawynok, Stevens and Wynne, p. 123.

${ }^{39}$ Rose et al. state:

A justification for restrictive welfare policies is exemplified by the "benefit of the doubt" dogma. This brand of logic peculiar to welfare biology is, in effect, an admission that the fish pain issue is not resolved (hence the doubt), but the consequence is to mandate policy as if the matter actually was resolved in favour of fish pain interpretations. This is a social-political manoeuvre that effectively exempts valid science from policy.

Rose, Arlinghaus, Cooke, Diggles, Sawynok, Stevens and Wynne, pp. 123-4.

40 I note the latter question is not scientific in nature, but rather ethical and political, but it equally relates to how we understand and respond to truth. I am deliberately playing with Jeremy Bentham here, and his famous footnote, which proved influential for pro-animal discourse, at least in Peter Singer's foundational text Animal Liberation. See Jeremy Bentham, An Introduction to the Principles of Morals and Legislation, Chapter XIX, Note §. From my perspective, and against Benthem's, the question should neither be can they think, can they reason nor can they suffer, but instead, 'why it is that we can justify using animals in the way we do when there is the possibility, every possibility, that they think, reason and suffer as we do?'

41 On this politics, see Wendy Brown, States of Injury: Power and Freedom in Late Modernity, Princeton University Press, Princeton, 1995; and Wendy Brown, 'Suffering Rights as Paradoxes,' Constellations. 7.2, 2000, pp. 230-241. doi: 10.1111/1467-8675.00183.

42 This should not seem strange to those who have engaged in a variety of other social justice struggles. Feminists have, for example, fought for decades to have domestic and sexual violence recognised in domestic and international law as violence worthy of legal attention. This is an epistemic problem, in so far as the law, and by extension, patriarchy, have systematically failed to see acts of domestic and sexual violence as constituting violence, have failed to recognise perpetrators as wielding violence (so, for example, men are configured as unlucky, or unwitting, or victims themselves) and finally have 
situated women as not having a subjecthood that can be violated, or are open to violation without protection of the law under particular circumstances (such as in the home).

43 Gayatri Chakravorty Spivak, 'Can the Subaltern Speak?', in C. Nelson and L. Grossberg (eds), Marxism and the Interpretation of Culture, Macmillan Education, Basingstoke, 1988, pp. 271-313.

${ }^{44}$ On the international gender politics of 'customary practice', see Dicle Kogacioglu, 'The Tradition Effect: Framing Honor Crimes in Turkey', differences: A Journal of Feminist Cultural Studies, vol. 15, no. 2, 2004, pp. 119-51. doi: 10.1215/10407391-15-2-118.

45 Spivak, p. 93.

46 Brown, p. 231.

47 See for example Gary Francione's critique of animal welfare: Gary L. Francione, Animals, Property and the Law, Temple University Press, Philadelphia, 2007. See also Donaldson and Kymlicka, p. 2 and Peter Sankoff, 'The Welfare Paradigm: Making the World a Better Place for Animals?', in Peter Sankoff and Steven White (eds), Animal Law in Australasia: A New Dialogue, The Federation Press, Sydney, 2009. 48 Deirdre Bourke, 'The Use and Misuse of “Rights Talk” by the Animal Rights Movement', in Peter Sankoff and Steven White (eds), Animal Law in Australasia: A New Dialogue, The Federation Press, Sydney, 2009, p. 133.

${ }^{49}$ See, for example, Adam Shriver, 'Knocking Out Pain in Livestock: Can Technology Succeed Where Morality has Stalled?', Neuroethics, vol. 2, no. 3, 2009, pp. 115-24. doi: 10.1007/s12152-009-9048-6. See also Richard Twine, Animals as Biotechnology: Ethics, Sustainability and Critical Animal Studies, Routledge/Earthscan, London, 2010.

50 One example of this sort of argument is Christie Wilcox, 'Bambi or Bessie: Are Wild Animals Happier?', Scientific American, 12 April 2011 at <http://blogs.scientificamerican.com/guestblog/2011/04/12/bambi-or-bessie-are-wild-animals-happier/>. Note that Bentham's famous footnote on animals more or less contained the same assertion:

If the being eaten were all, there is very good reason why we should be suffered to eat such of them as we like to eat: we are the better for it, and they are never the worse. They have none of those long-protracted anticipations of future misery which we have. The death they suffer in our hands commonly is, and always may be, a speedier, and by that means a less painful one, than that which would await them in the inevitable course of nature. If the being killed were all, there is very good reason why we should be suffered to kill such as molest us: we should be the worse for their living, and they are never the worse for being dead. But is there any reason why we should be suffered to torment them?

See Jeremy Bentham, An Introduction to the Principles of Morals and Legislation, Library of Economics and Liberty, 23 March 2016, <http://www.econlib.org/library/Bentham/bnthPML18.html>, Chapter XVII, n122. A variation of this argument is the view that vegetarian diets lead to more death: 'relying on grains and pulses brings destruction of native ecosystems, significant threats to native species and at least 25 times more deaths of sentient animals per kilogram of food'. See Mike Archer, 'Ordering the 
Vegetarian Meal? There is More Blood on Your Hands', The Conversation, 16 December 2011, $<$ http://theconversation.com/ordering-the-vegetarian-meal-theres-more-animal-blood-on-yourhands-4659>.

${ }^{51}$ An example of this is the use of the phrase 'balanced harvest' to effectively describe targeted killing of fish species in order to maintain adequate population numbers to ensure reproductive viability and future sustainability. See United Nations Food and Agriculture Organization, The State of World Fisheries and Aquaculture, pp. 136-41.

$52 \mathrm{~A}$ prominent critique of making this assumption is that it relies on a 'sentimental anthropomorphism'. We see elements of this critique advanced in Elspeth Probyn's recent work on fishing, which in its care to not employ anthropocentric views on what fish may want, fails to engage with the welfare issues that might attend the use of fish for food, and the violence of this use. Probyn states:

In terms of our own areas of study, the complex and vexed questions of eating and human and non-human relations cannot be reduced to which species is most anthropomorphically endowed. If we are truly to advance a program of research, and of ethics, in eating we need to attend to both the singularity of species as well as our mutuality. This is a tough call, but necessary if we are to attend to the material conditions of what makes for emotional geographies and for whom. As researchers we are compelled to pay close attention to the faceted aspects of life, recognizing the multiplicity of what makes things feel. We may not like that the tuna men are businessmen, but they are also complex people with ties to places, fish, families, and communities and of course the sea. We do not know what tuna feel, and to speculate on that risks drawing us into the false security of sentimental comfort.

Elspeth Probyn, 'Swimming with Tuna: Human-Ocean Entanglements', Australian Humanities Review, no. 51, 2011, pp. 97-114. Probyn is attempting to avoid a kind of epistemic violence that arises from sentimentality; however, I think there is a 'sentimental comfort' in assuming that 'the fish actually wanted to die'. This is surely a central and comfortable assumption that allows mainstay violent practices against animals to continue.

53 See Jason Hribal, “'Animals Are Part of the Working Class”: A Challenge to Labor History', Labor History, vol. 44, no. 4, 2003, 448-50. doi: 10.1080/0023656032000170069. See also, Jason Hribal, Fear of the Animal Planet: The Hidden History of Animal Resistance, AK Press/Counter Punch Books, Oakland, 2010.

${ }^{54}$ Hribal, Fear of the Animal Planet, 'Epilogue: When Orcas Resist'; Gabriela Cowperthwaite, Blackfish, Documentary, Dogwoof, 2013.

55 Herman Melville, Moby Dick, Dover Publications, Mineola, 2003.

56 Ernest Hemingway, The Old Man and the Sea, Scribner, New York, 1952. 
57 See Dinesh Joseph Wadiwel, 'The Will for Self-Preservation: Locke and Derrida on Dominion, Property and Animals', Sub-Stance, vol. 43, no. 2, 2014, pp. 148-61. doi: 10.1353/sub.2014.0029.

58 In this regard, see Adrian Franklin's discussion of trout fishing and the contesting agencies between fish and anglers; Adrian Stephen Franklin, 'Performing Acclimatisation: The Agency of Trout Fishing in Postcolonial Australia', Ethnos: Journal of Anthropology, vol. 76, no. 1, 2011, pp. 19-40. doi: 10.1080/00141844.2010.537759.

${ }^{59}$ Agnieszka Kowalczyk, 'Mapping Non-Human Resistance in the Age of Biocapital', in Nik Taylor and Richard Twine (eds), The Rise of Critical Animal Studies: From Margins to Centre, Routledge, London and New York, 2014, p. 194. In relation to fish agency and Kantian ethics, see Frederike Kaldewaij, 'Does Fish Welfare Matter? On the Moral Relevance of Agency', Journal of Agricultural Environmental Ethics, no. 26, 2013, pp. 63-74. doi: 10.1007/s10806-011-9372-9.

${ }^{60}$ Clare A. Palmer, 'Taming the Wild Profusion of Existing Things? A Study of Foucault, Power and Human/Animal Relationships', Environmental Ethics, vol. 23, no. 494, 2001, pp. 339-58.

61 Palmer, 'Taming the Wild Profusion of Existing Things?', p. 354. See also Jonathan L. Clark on animal resistance in Jonathan L. Clark, 'Labourers or Lab Tools? Rethinking the Role of Lab Animals in Clinical Trials', in Nik Taylor and Richard Twine (ed.), The Rise of Critical Animal Studies: From Margins to Centre, Routledge, London and New York, 2014, pp. 139-64.

62 See Tim Ingold, The Perception of the Environment: Essays on Livelihood, Dwelling and Skill, Routledge, London and New York, 2006, p. 73.

63 Ibid. Note Ingold's observation that sentience plus resistance to violence demonstrates a form of agency.

${ }^{64}$ For one summary of the operaist tendency, see Sandro Mezzadra, 'Italy, Operaism and PostOperaism', in Immanuel Ness (ed.), International Encyclopedia of Revolution and Protest, Blackwell Publishing, Oxford, 2009, pp. 1841-5. See, for example, Fahim Amir, 'Zooperaismus: 'Über den Tod hinaus leisteten die Schweine Widerstand...', Presentation at Critique of Political Zoology Conference, Hamburg, 14-15 June 2013. For a discussion of the relationship of pigeons to the city, see also Fahim Amir, '1000 Tauben: Vom Folgen und Fliehen, Aneignen, Stören und Besetzen', Eurozine, May 2013, <http://www.eurozine.com/articles/2013-05-07-amir-de.html >. The final lines read: 'Wo es Stadt gibt, da gibt es auch Stadttauben. Und wo es Stadttauben gibt, da gibt es auch Widerstand' (Where there is the city there are also pigeons. And where there are pigeons, there is also resistance). See also Kowalczyk, pp. 183-200.

65 See Noske's discussion of human domestication as a case of social parasitism, B. Noske, Beyond Boundaries: Humans and Animals, Black Rose Books, Montreal, 1997, pp. 4-5. See also Michel Serres, The Parasite, John Hopkins University Press, Baltimore, 1982.

66 I refer here to the process of 'real' subsumption that Karl Marx described in the Draft Chapter 6 of Capital ('The Direct Production Process') which proved influential for operaist conceptualisations. See 
Karl Marx, 'The Direct Production Process', Economic Works of Karl Marx 1861-1864, <https://www.marxists.org/archive/marx/works/1864/economic/ch02a.htm\#469a>. ${ }^{67}$ See Michael Hardt and Antoni Negri, Empire, Harvard University Press, Cambridge, 2000, pp. 272-6. See also Melissa Gregg, 'Freedom to Work: The Impact of Wireless on Labour Politics', Media International Australia, 'Special Issue on Wireless Technologies and Cultures', no. 125, 2007, pp. 57-70 and Melissa Gregg, 'Learning to (Love) Labour: Production Cultures and the Affective Turn', Communication and Critical/Cultural Studies, vol. 6, no. 2, 2009, pp. 209-14. doi: 10.1080/14791420902868045.

68 Mario Tronti, 'Our Operaismo', New Left Review, no. 73, 2012, pp. 119-39.

${ }^{69}$ See, for example, Temple Grandin, 'Race System for Cattle Slaughter Plants with 1.5m Radius Curves', Applied Animal Behaviour Science, no. 13, 1984/85, pp. 295-9. doi:10.1016/0168-1591(85)90053-X. 70 Ibid., p. 295.

71 See Wadiwel, 'Lubricative Power'.

72 Hardt and Negri, p. 32.

73 See Clare Palmer, Animal Ethics in Context, Columbia University Press, Columbia, 2010; John Law, 'Notes on Fish, Ponds and Theory', Norsk Antropologisk Tidskrift, nos 3-4, 2012, pp. 225-36; Donna J. Haraway, When Species Meet, University of Minnesota Press, Minneapolis, 2008; and Elspeth Probyn, 'The Cultural Politics of Fish and Humans: A More-Than-Human Habitus of Consumption', Cultural Politics, vol. 10, no. 3, 2014, pp. 287-99.

74 In some respects Elspeth Probyn's essay, 'The Cultural Politics of Fish and Humans', reveals the kinds of problems with a relational view of ethics that emphasises entanglement between human and non human, but chooses to not emphasise the structuring role of violence within these relationships. Probyn seeks to develop an ethic of 'care' in relation to fisherpeople, the ocean and the fish they seek to catch:

the ability to care in nuanced ways comes from a habitus imbued with the oceanic. But perhaps even more important than caring are the entanglements that our actions engender with others, both human and nonhuman. Coming to care, we become attached with others and imbricated with the movements of the ocean. A cultural politics of the more-than-human must, I think, smell of the sea and be open to the rocking relationships of people, fish, and ocean. (Probyn, p. 297)

As my essay suggests, this sort of perspective is only possible through an epistemic framing which denies violence and fish resistance to that violence.

75 See Sue O'Connor, Rintaro Ono and Chris Clarkson, 'Pelagic Fishing at 42,000 Years Before the Present and the Maritime Skills of Modern Humans', Science, vol. 334, no. 6059, 2011, pp. 1117-21. doi: 10.1126/science.1207703.

76 Richard Klein and Blake Edgar, The Dawn of Human Culture, John Wiley and Sons, Inc, New York, 2002, p. 18. 
77 Klein and Edgar, p. 20. See also Andres Von Brandt, Fish Catching Methods of the World, Fishing News Book, Farnham, 1984, p. 1.

78 See my discussion of John Locke, the 'commons' and property relationships in animals, Wadiwel, 'The Will for Self-Preservation'.

79 David M. Ewalt, 'The Twenty Most Important Tools Ever', Forbes 15 March 2006, <http://www.forbes.com/2006/03/14/technology-tools-history_cx_de_06toolsland.html>.

80 The hook is primarily a catch device; however, it is involved in killing even where fishing practices (such as 'catch and release') aim to avoid death. One study for example suggests and 18 per cent mortality rate for catch and release fish, and noting the difficulty of gaining a full picture of mortality rates, observes that 'many reported mortality estimates probably underestimate actual mortality, at least for marine species, because they rarely include predation during capture and after release, or consider cumulative mortality from multiple releases'. See Aaron Bartholomew and James A. Bohnsack, 'A Review of Catch-and-Release Angling Mortality with Implications for No-Take Reserves', Reviews in Fish Biology and Fisheries, no. 15, 2005, pp. 129-54, pp. 143-44. doi: 10.1007/s11160-005-2175-1. 81 Elaine Scarry, The Body in Pain: The Making and Unmaking of the World, Oxford University Press, New York, 1985, p. 47.

82 See Jeffrey A. Steina, Aaron D. Shultz, Steven J. Cooke, Andy J. Danylchuk, Kit Hayward and Cory D. Suski, 'The Influence of Hook Size, Type, and Location on Hook Retention and Survival of Angled Bonefish (Albula vulpes)', Fisheries Research, no. 113, 2012, pp. 147-52. doi:10.1016/j.fishres.2011.11.001.

${ }^{83}$ For one summary of research in this area, see Matt Barwick, 'Are Barbless Hooks Really Better?', Australian Government Fisheries Research and Development Corporation, 2012, <http://recfishingresearch.org/wp-content/uploads/2012/11/AreBarblessHooksBetter.pdf>. ${ }^{84}$ Sea Grant Florida, 'Circle Hooks', Sea Grant Florida, SGEF, no. 170, p. 1, <http://nsgl.gso.uri.edu/flsgp/flsgpg08003.pdf>. See also S.J. Cooke and C.D. Suski, 'Are Circle Hooks an Effective Tool for Conserving Marine and Freshwater Recreational Catch-and-Release Fisheries?', Aquatic Conservation: Marine Freshwater Ecosystems, no. 14, 2004, pp. 299-326. doi: 10.1002/aqc.614. 85 Sea Grant Florida, p. 2.

86 See Von Brandt.

${ }^{87}$ See, for example, Paul K. Dayton, Simon F. Thrush, M. Tundi Agardy and Robert J. Hofman, 'Environmental Effects of Marine Fishing', Aquatic Conservation: Marine and Freshwater Ecosystems, vol. 5, no. 3, 1995, pp. 205-232. doi: 10.1002/aqc.3270050305; J.B. Jones, 'Environmental Impact of Trawling on the Seabed: A Review', New Zealand Journal of Marine and Freshwater Research, vol. 26, no. 1, 1992, pp. 59-67. doi: 10.1080/00288330.1992.9516500; United Nations Food and Agriculture Organisation, A Global Assessment of Fisheries Bycatch and Discards, FAO Fisheries Technical Paper No. 339, United Nations Food and Agriculture Organisation, 1996; Rebecca L. Lewison, Larry B. Crowder, Andrew J. Read and Sloan A. Freeman, 'Understanding Impacts of Fisheries Bycatch on Marine 
Megafauna', Trends in Ecology and Evolution, vol. 19, no. 11, 2004, pp. 598-604.

doi:10.1016/j.tree.2004.09.004; Clifford H. Ryer, 'Trawl Stress and Escapee Vulnerability to Predation in Juvenile Walleye Pollock: Is there an Unobserved Bycatch of Behaviorally Impaired Escapees?', Marine Ecology, no. 232, 2002, pp. 269-79; R.W.D. Davies, S.J. Cripps, A. Nickson, G. Porter, ‘Defining and Estimating Global Marine Fisheries Bycatch', Marine Policy, vol. 33, no. 4, 2009, pp. 661-72. doi:10.1016/j.marpol.2009.01.003; and Monin J. Amandè, Emmanuel Chassot, Pierre Chavance, Hilario Murua, Alicia Delgado de Molina, and Nicolas Bez, 'Precision in Bycatch Estimates: The Case of Tuna Purse-Seine Fisheries in the Indian Ocean', ICES Journal of Maritime Science, vol. 69, no. 8, 2012, pp. 1501-10. doi: 10.1093/icesjms/fss106.

88 See Mood, pp. 26-31.

${ }^{89}$ For a variety of studies on the sustainability and impact of purse seine fishing see, for example, Trond Bjørndal and Jon M. Conrad, 'The Dynamics of an Open Access Fishery', The Canadian Journal of Economics / Revue canadienne d'Economique, vol. 20, no. 1, 1987, pp. 74-85. doi: 10.2307/135232; A. Ménard, D. Fonteneau, V. Gaertner, B. Nordstrom, B. Stéquert and E. Marchal, 'Exploitation of Small Tunas by a Purse-Seine Fishery with Fish Aggregating Devices and their Feeding Ecology in an Eastern Tropical Atlantic Ecosystem', ICES Journal of Maritime Science, vol. 57, no. 3, 2000, pp. 525-30. doi: 10.1006/jmsc.2000.0717; Amandè et al.,'Precision in Bycatch Estimates.'; Dennis O'Connell, 'Tuna, Dolphins, and Purse Seine Fishing in the Eastern Tropical Pacific: The Controversy Continues', UCLA Journal of Environmental Law and Policy, vol. 23, no. 1, 2005, pp. 77-100; Amandè Monin, Javier Ariz, Emmanuel Chassot, Alicia Delgado de Molina, Daniel Gaertner, Hilario Murua, Renaud Pianet, Jon Ruiz and Pierre Chavance, 'Bycatch of the European Purse Seine Tuna Fishery in the Atlantic Ocean for the 2003-2007 Period', Aquatic Living Resources, no. 23, 2010, pp. 353-62. doi: 10.1051/alr/2011003; H.F Campbell, R.B. Nicholl and G. Meyer, 'Search Behavior in the Purse Seine Tuna Fishery', Natural Resource Modeling, vol. 7, no. 1, 1993, pp. 15-35; and A. Murillas-Maza, 'Spatial and Inter-temporal Economic Sustainability Assessment: A Case Study of the Open Oceans Basque Purse-seine Fleets', Proceedings of the 1st World Sustainability Forum, 1-30 November 2011, Sciforum Electronic Conference Series, vol. 1, 2011.

90 See Tim K. Davies, Chris C. Mees, E.J. Milner-Gulland, 'The Past, Present and Future Use of Drifting Fish Aggregating Devices (FADs) in the Indian Ocean', Marine Policy, 45, 2014, pp. 163-70. doi:10.1016/j.marpol.2013.12.014.

91 Martin Hall and Marlon Roman, Bycatch and Non-Tuna Catch in the Tropical Tuna Purse Seine Fisheries of the World, FAO Fisheries and Aquaculture Technical Paper No. 568, 2013, p. 10. 92 See Aud Vold, Jostein Saltskar and Irene Huse, 'Crowding in Purse Seine Can Kill Half the Catch of North Sea Herring', Marine Research, Institute of Marine Research, Working Paper No. 6, 2010; S.J. Lockwood, M.G. Pawson, D.R. Eaton, 'The Effects of Crowding on Mackerel (Scomber Scombrus): Physical Conditions and Mortality', Fisheries Research, no. 2, 1983, pp. 129-47. doi:10.1016/01657836(83)90114-5; and Maria Tenningen, Aud Vold and Rolf Erik Olsen, 'The Response of Herring to 
High Crowding Densities in Purse-Seines: Survival and Stress Reaction', ICES Journal of Marine Science, vol. 69, no. 8, 2012, pp. 1523-31. doi: 10.1093/icesjms/fss114. Conversely, where it is necessary to keep fish alive, such as when capturing them for aquaculture, then the purse will be 'stopped half way'. See Hall and Roman, p. 13.

93 For a visual outline of the purse seine set process, see Cambria Bold, 'One Way to Catch Salmon in Alaska: Onboard the Purse Seine Owyhee', The Kitchn, 15 August 2013,

$<$ http://www.thekitchn.com/this-is-one-way-to-catch-salmon-in-alaska-193566>.

94 See P.G. Schmidt, 'The Puretic Power Block and its Effect on Modern Purse Seining', Hilmar

Kristjansson (ed.), Modern Fishing Gear Of The World, FAO, Rome, 1959, pp. 400-14

95 See Von Brandt, pp. 2-3.

96 Food and Agriculture Organization of the United Nations, The State of World Fisheries and Aquaculture, 2014, pp. 3-10.

${ }^{97}$ See Q. Hanich and Y. Ota, 'Moving Beyond Rights Based Management: A Transparent Approach to Distributing the Conservation Burden in Tuna Fisheries', International Journal of Marine and Coastal Law, 2013, p. 28. doi: 10.1163/15718085-12341268; and Q. Hanich, B. Campbell. M. Bailey and E. Molenaar, 'Research into Fisheries Equity and Fairness: Addressing Conservation Burden Concerns in Transboundary Fisheries', Marine Policy, no. 51, 2015, pp. 302-4. doi:10.1016/j.marpol.2014.09.011. 98 For some different perspectives on this long history of domination, see Ingold, The Perception of the Environment; David. A. Nibert, Animal Oppression \& Human Violence: Domesecration, Capitalism and Global Conflict, Columbia University Press, New York, 2013; and Erica Fudge, 'The Animal Face of Early Modern England', Theory, Culture \& Society, vol. 32, no. 4, 2013, pp. 3-25. doi:

10.1177/0263276413496122.

99 Knowledge@Wharton, 'Aquaculture Is Needed to Satisfy Global Demand for Fish', Wharton, University of Pennsylvania, 18 October 2006,

$<$ http://knowledge.wharton.upenn.edu/article/aquaculture-is-needed-to-satisfy-global-demand-forfish/>.

100 M. Krkoŝek, C.W. Revie, P.G. Gargan, O.T. Skilbrei, B. Finstad, C.D. Todd, 'Impact of Parasites on Salmon Recruitment in the Northeast Atlantic Ocean', Proceedings Royal Society of London B Biological Sciences, vol. 280, 2013. doi: 10.1098/rspb.2012.2359; Samantha Bui, Frode Oppedal, Øyvind J. Korsøen and Tim Dempster, 'Modifying Atlantic Salmon Behaviour with Light or Feed Stimuli May Improve Parasite Control Techniques', Aquaculture Environmental Interactions, no. 3, 2013, pp. 125-33; Law, pp. 2-3. See for example Sigurd O. Handelanda, Albert K. Imslanda, and Sigurd O. Stefanssona, 'The Effect of Temperature and Fish Size on Growth, Feed Intake, Food Conversion Efficiency and Stomach Evacuation Rate of Atlantic Salmon Post-Smolts', Aquaculture, vol. 283, nos 1-4, 2008, pp. 36-42. doi:10.1016/j.aquaculture.2008.06.042.

101 Law, p. 9.

102 Ashley, 'Fish Welfare,' pp. 211-13. 
103 Ibid., p. 214. See also Bui et al.

104 Ashley, pp. 208-9.

105 Ashley, p. 208. See also David H.F. Robb, 'Welfare of Fish at Harvest', in Edward J. Branson (ed.), Fish Welfare, Blackwell, Oxford, 2008, pp. 217-42.

106 See Jenny Bergqvist and Stefan Gunnarsson, 'Finfish Aquaculture: Animal Welfare, the Environment, and Ethical Implications', Journal of Agricultural and Environmental Ethics, no. 26, 2013, pp. 82-3. doi: 10.1007/s10806-011-9346-y.

107 See Law.

108 In addition to the increased scholarly scientific interest in fish cognition, suffering and welfare, there have been developments in welfare protections relating to fish, such as legal protections which apply to farmed fish in Norway. In Australia there has been pioneering work in developing Aquatic Animal Welfare Guidelines and recognition of Aquatic Animals in the Australian Animal Welfare Strategy.

109 Michael Hardt and Antonio Negri, 'Marx's Mole is Dead! Globalisation and Communication', Eurozine, 13 February 2002, <http://www.eurozine.com/articles/2002-02-13-hardtnegri-en.html>.

\section{-BiBLIOGRAPHY}

Amandè, M.J., E. Chassot, P. Chavance, H. Murua, A. Delgado de Molina and N. Bez, 'Precision in Bycatch Estimates: The Case of Tuna Purse-Seine Fisheries in the Indian Ocean', ICES Journal of Maritime Science, vol. 69, no. 8, 2012. doi: http://dx.doi.org/10.1093/icesjms/fss106

Amir, F., '1000 Tauben: Vom Folgen und Fliehen, Aneignen, Stören und Besetzen', Eurozine, May 2013, <http://www.eurozine.com/articles/2013-05-07-amir-de.html >.

Amir, F., 'Zooperaismus: 'Über den Tod hinaus leisteten die Schweine Widerstand...', Presentation at Critique of Political Zoology Conference, Hamburg, 14-15 June 2013.

Animals Australia, 'Fishing', Animals Australia, <http://www.animalsaustralia.org/issues/fishing.php>. Animals Australia, 'Fishing: Can They Suffer? Do They Feel Pain? Understanding the Creatures of the Marine Kingdom', Animals Australia, <http://www.animalsaustralia.org/issues/fishing.php>. Archer, M., 'Ordering the Vegetarian Meal? There is More Blood on Your Hands', The Conversation, 16 December 2011, <http://theconversation.com/ordering-the-vegetarian-meal-theres-moreanimal-blood-on-your-hands-4659>.

Ashley, P.J., 'Fish Welfare: Current Issues in Aquaculture', Applied Animal Behaviour Science, vol. 104, 2007, pp. 199-235. doi: http://dx.doi.org/10.1016/j.applanim.2006.09.001

Australian Animal Welfare Strategy, Commercial Capture Fishing Guidelines, <http://www.australiananimalwelfare.com.au/content/aquatic-animals/commercial-capturefishing-guidelines $2>$.

Bartholomew, A. and J.A. Bohnsack, 'A Review of Catch-and-Release Angling Mortality with Implications for No-Take Reserves', Reviews in Fish Biology and Fisheries, no. 15, 2005. doi: http://dx.doi.org/10.1007/s11160-005-2175-1 
Barwick, M., 'Are Barbless Hooks Really Better?', Australian Government Fisheries Research and Development Corporation, 2012, <http://recfishingresearch.org/wpcontent/uploads/2012/11/AreBarblessHooksBetter.pdf>.

Bentham, J., An Introduction to the Principles of Morals and Legislation, Library of Economics and Liberty, 23 March 2016, <http://www.econlib.org/library/Bentham/bnthPML18.html>.

Bergqvist, J. and S. Gunnarsson, 'Finfish Aquaculture: Animal Welfare, the Environment, and Ethical Implications', Journal of Agricultural and Environmental Ethics, no. 26, 2013. doi: http://dx.doi.org/10.1007/s10806-011-9346-y

Bjørndal, T. and J.M. Conrad, 'The Dynamics of an Open Access Fishery', The Canadian Journal of Economics / Revue canadienne d'Economique, vol. 20, no. 1, 1987. doi: http://dx.doi.org/10.2307/135232

Black, C., 'The Conundrum of Fish Welfare', in P. Sankoff, S. White, C. Black (ed.), Animal Law in Australasia: Continuing the Dialogue, 2nd edn, Federation Press, Sydney, 2012.

Bold, C., 'One Way to Catch Salmon in Alaska: Onboard the Purse Seine Owyhee', The Kitchn, 15 August 2013, <http://www.thekitchn.com/this-is-one-way-to-catch-salmon-in-alaska-193566>.

Bourke, D., 'The Use and Misuse of "Rights Talk" by the Animal Rights Movement', in P. Sankoff and S. White (eds), Animal Law in Australasia: A New Dialogue, The Federation Press, Sydney, 2009.

Braithwaite, V.A. and F.A. Huntingford, 'Fish and Welfare: Can Fish Perceive Pain and Suffering?', Animal Welfare, no. 13, 2004.

Braithwaite, V.A., Do Fish Feel Pain? Oxford University Press, Oxford, 2010.

Brown, C., 'Fish Intelligence, Sentience and Ethics', Animal Cognition, vol. 18, no. 1, 2015. doi: http://dx.doi.org/10.1007/s10071-014-0761-0

Brown, W., 'Suffering Rights as Paradoxes,' Constellations, vol. 7, no. 2, 2000. doi: http://dx.doi.org/10.1111/1467-8675.00183

Brown, W., States of Injury: Power and Freedom in Late Modernity, Princeton University Press, Princeton, NJ, 1995.

Bui, S., F. Oppedal, Ø.J. Korsøen, T. Dempster, 'Modifying Atlantic Salmon Behaviour with Light or Feed Stimuli May Improve Parasite Control Techniques', Aquaculture Environmental Interactions, no. $3,2013$.

Campbell, H.F, R.B. Nicholl and G. Meyer, 'Search Behavior in the Purse Seine Tuna Fishery', Natural Resource Modeling, vol. 7, no. 1, 1993.

Caulfield, M., Handbook of Australian Animal Cruelty Law, Animals Australia, Sydney, 2008.

Clark, J.L., 'Labourers or Lab Tools? Rethinking the Role of Lab Animals in Clinical Trials', in N. Taylor and R. Twine (ed.) The Rise of Critical Animal Studies: From Margins to Centre, Routledge, London and New York, 2014. 
Cooke, S.J. and C.D. Suski, 'Are Circle Hooks an Effective Tool for Conserving Marine and Freshwater Recreational Catch-and-Release Fisheries?', Aquatic Conservation: Marine Freshwater Ecosystems, no. 14, 2004. doi: http://dx.doi.org/10.1002/aqc.614

Cottingham, J., 'A Brute to the Brutes? Descartes' Treatment of Animals', Philosophy, vol. 53, 1978. Cowperthwaite, G., Blackfish, Documentary, Dogwoof, 2013.

Crutzen, P.J. and E.F. Stoermer, 'The "Anthropocene”', Global Change Newsletter (IGBP), no. 41, 2000.

Crutzen, P.J., 'Geology of Mankind', Nature, vol. 415, 2000.

Davies, R.W.D., S.J. Cripps, A. Nickson, G. Porter, 'Defining and Estimating Global Marine Fisheries Bycatch', Marine Policy, vol. 33, no. 4, 2009. doi: http://dx.doi.org/10.1016/j.marpol.2009.01.003

Davies, T.K., C.C. Mees, E.J. Milner-Gulland, 'The Past, Present and Future Use of Drifting Fish Aggregating Devices (FADs) in the Indian Ocean', Marine Policy, no. 45, 2014. doi: http://dx.doi.org/10.1016/j.marpol.2013.12.014

Dayton, P.K., S.F. Thrush, M.T. Agardy and R.J. Hofman, 'Environmental Effects of Marine Fishing', Aquatic Conservation: Marine and Freshwater Ecosystems, vol. 5, no. 3, 1995. doi: http://dx.doi.org/10.1002/aqc.3270050305

Donaldson, S. and W. Kymlicka, Zoopolis: A Political Theory of Animal Rights, Oxford University Press, Oxford, 2011.

Ewalt, D,M., 'The Twenty Most Important Tools Ever', Forbes, 15 March 2006, <http://www.forbes.com/2006/03/14/technology-tools-history_cx_de_06toolsland.html>.

Fishcount.org.uk, 'Humane Slaughter', Fishcount.org.uk, <http://fishcount.org.uk/fish-welfare-incommercial-fishing/humane-slaughter>.

Fisheries Society of the British Isles (FSBI), Fish Welfare, Briefing Report 2, 2002.

Food and Agriculture Organization of the United Nations, FAOSTAT, 2010 data, <www.faostat.fao.org>. Food and Agriculture Organization of the United Nations, The State of World Fisheries and Aquaculture, 2014, Food and Agriculture Organization of the United Nations, Rome, 2014.

Foucault, M., The Courage of Truth: Lectures at the Collège de France 1983-1984, Palgrave MacMillan, New York, 2011. doi: http://dx.doi.org/10.1057/9780230309104

Foucault, M., The Government of Self and Others: Lectures at the Collège de France 1982-1983, Palgrave Macmillan, New York, 2010. doi: http://dx.doi.org/10.1057/9780230274730

Foucault, M., Security, Territory, Population: Lectures at the Collège de France, 1977-78, Palgrave Macmillan, London, 2007. doi: http://dx.doi.org/10.1057/9780230245075

Foucault, M., The History of Sexuality Volume 1: The Will to Knowledge, Penguin Books, London, 1998. Foucault, M., The Order of Things: An Archeology of the Human Sciences, Vintage Books, New York, 1994. Francione, G.L., Animals, Property and the Law, Temple University Press, Philadelphia, 2007. 
Franklin, A.S., 'Performing Acclimatisation: The Agency of Trout Fishing in Postcolonial Australia', Ethnos: Journal of Anthropology, vol. 76, no. 1, 2011. doi: http://dx.doi.org/10.1080/00141844.2010.537759

Fudge, E., 'The Animal Face of Early Modern England', Theory, Culture \& Society, vol. 32, no. 4, 2013. doi: http://dx.doi.org/10.1177/0263276413496122

Grandin, T., 'Race System for Cattle Slaughter Plants with 1.5m Radius Curves', Applied Animal Behaviour Science, no. 13, 1984/85. doi: http://dx.doi.org/10.1016/0168-1591(85)90053-X

Gregg, M., 'Freedom to Work: The Impact of Wireless on Labour Politics', Media International Australia, 'Special Issue on Wireless Technologies and Cultures', no. 125, 2007.

Gregg, M., 'Learning to (Love) Labour: Production Cultures and the Affective Turn', Communication and Critical/Cultural Studies, vol. 6, no. 2, 2009. doi: http://dx.doi.org/10.1080/14791420902868045

Hall, M, and M. Roman, Bycatch and Non-Tuna Catch in the Tropical Tuna Purse Seine Fisheries of the World, FAO Fisheries and Aquaculture Technical Paper No. 568, 2013.

Handelanda, S.O., A.K. Imslanda, and S.O. Stefanssona, "The Effect of Temperature and Fish Size on Growth, Feed Intake, Food Conversion Efficiency and Stomach Evacuation Rate of Atlantic Salmon Post-Smolts', Aquaculture, vol. 283, nos 1-4, 2008. doi: http://dx.doi.org/10.1016/j.aquaculture.2008.06.042

Hanich, Q. and Y. Ota, 'Moving Beyond Rights Based Management: A Transparent Approach to Distributing the Conservation Burden in Tuna Fisheries', International Journal of Marine and Coastal Law, 2013. doi: http://dx.doi.org/10.1163/15718085-12341268

Hanich, Q., B. Campbell. M. Bailey and E. Molenaar, 'Research into Fisheries Equity and Fairness: Addressing Conservation Burden Concerns in Transboundary Fisheries', Marine Policy, no. 51, 2015. doi: http://dx.doi.org/10.1016/j.marpol.2014.09.011

Haraway, D.J., When Species Meet, University of Minnesota Press, Minneapolis, 2008.

Hardt, M. and A. Negri, 'Marx's Mole is Dead! Globalisation and Communication', Eurozine, 13 February 2002, <http://www.eurozine.com/articles/2002-02-13-hardtnegri-en.html>.

Hardt, M. and A. Negri, Empire, Harvard University Press, Cambridge, 2000.

Hemingway, E., The Old Man and the Sea, Scribner, New York, 1952.

Hribal, J., “'Animals Are Part of the Working Class”: A Challenge to Labor History', Labor History. vol. 44, no. 4, 2003. doi: http://dx.doi.org/10.1080/0023656032000170069

Hribal, J., Fear of the Animal Planet: The Hidden History of Animal Resistance, AK Press/Counter Punch Books, Oakland, 2010.

Ingold, T., The Perception of the Environment: Essays on Livelihood, Dwelling and Skill, Routledge, London and New York, 2006. 
Jones, J.B., 'Environmental Impact of Trawling on the Seabed: A Review', New Zealand Journal of Marine and Freshwater Research, vol. 26, no. 1, 1992. doi: http://dx.doi.org/10.1080/00288330.1992.9516500

Kaldewaij, F., 'Does Fish Welfare Matter? On the Moral Relevance of Agency', Journal of Agricultural Environmental Ethics, no. 26, 2013, pp. 63-74. doi: http://dx.doi.org/10.1007/s10806-0119372-9

Key, B., 'Why Fish Do Not Feel Pain', Animal Sentience, vol. 1, no. 3, 2016, $<$ http://animalstudiesrepository.org/animsent/vol1/iss3/1/>.

Klein, R. and B. Edgar, The Dawn of Human Culture, John Wiley and Sons, Inc., New York, 2002.

Knowledge@Wharton, 'Aquaculture Is Needed to Satisfy Global Demand for Fish', Wharton, University of Pennsylvania, 18 October 2006, <http://knowledge.wharton.upenn.edu/article/aquacultureis-needed-to-satisfy-global-demand-for-fish/>.

Kogacioglu, D., 'The Tradition Effect: Framing Honor Crimes in Turkey', differences: A Journal of Feminist Cultural Studies, vol. 15, no. 2, 2004. doi: http://dx.doi.org/10.1215/10407391-15-2$\underline{118}$

Kowalczyk, A., 'Mapping Non-Human Resistance in the Age of Biocapital', in N. Taylor and R. Twine (eds), The Rise of Critical Animal Studies: From Margins to Centre, Routledge, London and New York, 2014.

Krkoŝek, M., C.W. Revie, P.G. Gargan, O.T. Skilbrei, B. Finstad, C.D. Todd, 'Impact of Parasites on Salmon Recruitment in the Northeast Atlantic Ocean', Proceedings Royal Society of London B Biological Sciences, vol. 280, no. 20122359, 2013. doi: http://dx.doi.org/10.1098/rspb.2012.2359

Law, J., 'Notes on Fish, Ponds and Theory', Norsk Antropologisk Tidskrift, nos 3-4, 2012.

Lewison, R.L., L.B. Crowder, A.J. Read and S.A. Freeman, 'Understanding Impacts of Fisheries Bycatch on Marine Megafauna', Trends in Ecology and Evolution, vol. 19, no. 11, 2004. doi: http://dx.doi.org/10.1016/j.tree.2004.09.004

Lockwood, S.J., M.G. Pawson and D.R. Eaton, 'The Effects of Crowding on Mackerel (Scomber Scombrus): Physical Conditions and Mortality', Fisheries Research, no. 2, 1983. doi: http://dx.doi.org/10.1016/0165-7836(83)90114-5

Marshall, M., 'Farmed Fish Overtakes Farmed Beef for First Time', New Scientist, 19 June 2013, <http://www.newscientist.com/article/dn23719-farmed-fish-overtakes-farmed-beef-for-firsttime.html\#.VLSaUiuUeP8>.

Marx, K., 'The Direct Production Process', Economic Works of Karl Marx 1861-1864, <https://www.marxists.org/archive/marx/works/1864/economic/ch02a.htm\#469a>.

Melville, H., Moby Dick, Dover Publications, Mineola, 2003.

Ménard, A., D. Fonteneau, V. Gaertner, B. Nordstrom, B. Stéquert and E. Marchal, 'Exploitation of Small Tunas by a Purse-Seine Fishery with Fish Aggregating Devices and their Feeding Ecology in an 
Eastern Tropical Atlantic Ecosystem', ICES Journal of Maritime Science, vol. 57, no. 3, 2000. doi: http://dx.doi.org/10.1006/jmsc.2000.0717

Mezzadra, S., 'Italy, Operaism and Post-Operaism', in I. Ness (ed.), International Encyclopedia of Revolution and Protest, Blackwell Publishing, Oxford, 2009.

Monin, A., J. Ariz, E. Chassot, A. Delgado de Molina, D. Gaertner, H. Murua, R. Pianet, J. Ruiz and P. Chavance, 'Bycatch of the European Purse Seine Tuna Fishery in the Atlantic Ocean for the 2003-2007 Period', Aquatic Living Resources, no. 23, 2010. doi: http://dx.doi.org/10.1051/alr/2011003

Mood, A. and P. Brooke, 'Estimating the Number of Farmed Fish Killed in Global Aquaculture Each Year', Fishcount.org.uk, 2012.

Mood, A., Worse Things Happen at Sea: The Welfare of Wild-Caught Fish, Fishcount.org.uk, 2010.

Murillas-Maza, A., 'Spatial and Inter-temporal Economic Sustainability Assessment: A Case Study of the Open Oceans Basque Purse-seine Fleets', Proceedings of the 1st World Sustainability Forum, 130 November 2011, Sciforum Electronic Conference Series, vol. 1, 2011.

Nibert, D.A., Animal Oppression \& Human Violence: Domesecration, Capitalism and Global Conflict, Columbia University Press, New York, 2013.

Noske, B., Beyond Boundaries: Humans and Animals, Black Rose Books, Montreal, 1997.

Nussbaum, M.C., 'Beyond 'Compassion and Humanity', in C.R. Sunstein and M.C. Nussbaum (eds), Animal Rights: Current Debates and New Directions, Oxford University Press, Oxford, 2004.

Nussbaum, M.C., Frontiers of Justice: Disability, Nationality, Species Membership, Harvard University Press, Cambridge, MA, 2006.

O'Connell, D., 'Tuna, Dolphins, and Purse Seine Fishing in the Eastern Tropical Pacific: The Controversy Continues', UCLA Journal of Environmental Law and Policy, vol. 23, no. 1, 2005. doi: http://dx.doi.org/10.1126/science.1207703

O'Connor, S., R. Ono and C. Clarkson, 'Pelagic Fishing at 42,000 Years Before the Present and the Maritime Skills of Modern Humans', Science, vol. 334, no. 6059, 2011. doi: 10.1126/science.1207703.

Palmer, C., Animal Ethics in Context, Columbia University Press, Columbia.

Palmer, C.A., 'Taming the Wild Profusion of Existing Things? A Study of Foucault, Power and Human/Animal Relationships,' Environmental Ethics, vol. 23, no. 494, 2001.2010.

Peter Sankoff, 'The Welfare Paradigm: Making the World a Better Place for Animals?', in P. Sankoff and S. White (eds), Animal Law in Australasia: A New Dialogue, The Federation Press, Sydney, 2009.

Poli, B.M., G. Parisi, F. Scappini, G. Zampacavallo, 'Fish Welfare and Quality as Affected by Pre-Slaughter and Slaughter Management', Aquaculture International, vol. 13, 2005. doi: http://dx.doi.org/10.1007/s10499-004-9035-1

Probyn, E., 'Swimming with Tuna: Human-Ocean Entanglements', Australian Humanities Review, no. 51, 2011. 
Probyn, E., 'The Cultural Politics of Fish and Humans: A More-Than-Human Habitus of Consumption', Cultural Politics, vol. 10, no. 3, 2014. doi: http://dx.doi.org/10.1215/17432197-2795681

Regan, T., The Case for Animal Rights, University of California Press, Berkeley, 1983.

Robb, D.H.F., 'Welfare of Fish at Harvest', in E.J. Branson (ed.), Fish Welfare, Blackwell, Oxford, 2008. doi: http://dx.doi.org/10.1002/9780470697610.ch14

Rose, J.D., 'The Neurobehavioral Nature of Fishes and the Question of Awareness and Pain', Reviews in Fisheries Science, vol. 10, no. 1, 2002. doi: http://dx.doi.org/10.1080/20026491051668

Rose, J.D., R. Arlinghaus, S.J. Cooke, B.K. Diggles, W. Sawynok, E.D. Stevens, C.D.L. Wynne, 'Can Fish Really Feel Pain?', Fish and Fisheries, vol. 15, no. 1, 2014. doi: http://dx.doi.org/10.1111/faf.12010

Ryer, C.H., 'Trawl Stress and Escapee Vulnerability to Predation in Juvenile Walleye Pollock: Is there an Unobserved Bycatch of Behaviorally Impaired Escapees?', Marine Ecology, no. 232, 2002.

Salter, M., 'Fishos Buoyed by “Fish Pain” Study', Fishing World, 24 January 2013, <http://www.fishingworld.com.au/news/blog-fishos-buoyed-by-fish-pain-study>.

Scarry, E., The Body in Pain: The Making and Unmaking of the World, Oxford University Press, New York, 1985.

Schmidt, P.G., 'The Puretic Power Block and its Effect on Modern Purse Seining', in Hilmar Kristjansson (ed.), Modern Fishing Gear Of The World, FAO, Rome, 1959.

Sea Grant Florida, 'Circle Hooks', Sea Grant Florida, SGEF, no. 170, <http://nsgl.gso.uri.edu/flsgp/flsgpg08003.pdf>.

Serres, M., The Parasite, John Hopkins University Press, Baltimore, 1982.

Shriver, A., 'Knocking Out Pain in Livestock: Can Technology Succeed Where Morality has Stalled?', Neuroethics, vol. 2, no. 3, 2009. doi: http://dx.doi.org/10.1007/s12152-009-9048-6

Singer, P., 'Fish: The Forgotten Victims on Our Plate', The Guardian, 14 September 2010, at <http://www.theguardian.com/commentisfree/cif-green/2010/sep/14/fish-forgottenvictims>.

Singer, P., 'Speciesism and Moral Status', Metaphilosophy, vol. 40, nos 3-4, 2009. doi: http://dx.doi.org/10.1111/j.1467-9973.2009.01608.x

Singer, P., Animal Liberation, Jonathan Cape, London, 1975.

Smallwood, C.B., K.H. Pollock, B.S. Wise, N.G. Hall and D.J. Gaughan, Quantifying Recreational Fishing Catch and Effort: A Pilot Study of Shore-based Fishers in the Perth Metropolitan Area, Fisheries Research Report no. 216, Final NRM Report-Project No. 09040, Department of Fisheries, Western Australia, 2011.

Sneddon, L.U., 'The Evidence for Pain in Fish: the Use of Morphine as an Analgesic', Applied Animal Behaviour Science, vol. 83, no. 2, 2003. doi: http://dx.doi.org/10.1016/S0168-1591(03)00113-8 
Sneddon, L.U., V.A. Braithwaite and M.J. Gentle, 'Do Fish Have Nociceptors?: Evidence for the Evolution of a Vertebrate Sensory System', Proceedings of the Royal Society London Series B, vol. 270, no. 1520, 2003, pp. 1115-1121. doi: http://dx.doi.org/10.1098/rspb.2003.2349

Spivak, G.C., 'Can the Subaltern Speak?', in C. Nelson and L. Grossberg (eds), Marxism and the Interpretation of Culture, Macmillan Education, Basingstoke, 1988. doi: http://dx.doi.org/10.1007/978-1-349-19059-1 20

Steina, J.A., A.D. Shultz, S.J. Cooke, A.J. Danylchuk, K. Hayward and C.D. Suski, 'The Influence of Hook Size, Type, and Location on Hook Retention and Survival of Angled Bonefish (Albula vulpes)', Fisheries Research, no. 113, 2012. doi: http://dx.doi.org/10.1016/j.fishres.2011.11.001

Tenningen, M., A. Vold and R.E. Olsen, 'The Response of Herring to High Crowding Densities in PurseSeines: Survival and Stress Reaction', ICES Journal of Marine Science, vol. 69, no. 8, 2012. doi: http://dx.doi.org/10.1093/icesjms/fss114

Tronti, M., 'Our Operaismo', New Left Review, no. 73, 2012.

Twine, R., Animals as Biotechnology: Ethics, Sustainability and Critical Animal Studies, Routledge/Earthscan, London, 2010.

United Nations Food and Agriculture Organisation, A Global Assessment of Fisheries Bycatch and Discards, FAO Fisheries Technical Paper no. 339, United Nations Food and Agriculture Organisation, 1996.

United Nations Food and Agriculture Organization, The State of World Fisheries and Aquaculture.

Vold, A., J. Saltskar and I. Huse, 'Crowding in Purse Seine Can Kill Half the Catch of North Sea Herring', Marine Research, Institute of Marine Research, Working Paper no. 6, 2010.

Von Brandt, A., Fish Catching Methods of the World, Fishing News Book, Farnham, 1984.

Wadiwel, D.J., 'Fish and Pain: The Politics of Doubt', Animal Sentience, vol. 1, no. 3, 2016, <http://animalstudiesrepository.org/animsent/vol1/iss3/31/>.

Wadiwel, D.J., The War against Animals, Brill and Rodopi, Leiden and Boston, 2015. doi: http://dx.doi.org/10.1163/9789004300422

Wadiwel, D.J., 'The Will for Self-Preservation: Locke and Derrida on Dominion, Property and Animals', Sub-Stance, vol. 43, no. 2, 2014,. doi: http://dx.doi.org/10.1353/sub.2014.0029

Wadiwel, D.J., 'Lubricative Power', Theory and Event, vol. 12, no. 4, 2009. doi: http://dx.doi.org/10.1353/tae.0.0090

Weber, M., Economy and Society: An Outline of Interpretive Sociology, vol. 1, Bedminister Press, New York, 1968.

Webster, J., 'Farm Animal Welfare: The Five Freedoms and the Free Market', Veterinary Journal, vol. 161, no. 3, 2004. doi: http://dx.doi.org/10.1053/tvjl.2000.0563

Wilcox, C., 'Bambi or Bessie: Are Wild Animals Happier?', Scientific American, 12 April 2011, <http://blogs.scientificamerican.com/guest-blog/2011/04/12/bambi-or-bessie-are-wildanimals-happier/>. 